Research Article

\title{
Plant Growth-Promoting Rhizobacteria Isolated from Degraded Habitat Enhance Drought Tolerance of Acacia (Acacia abyssinica Hochst. ex Benth.) Seedlings
}

\author{
Alemayehu Getahun, ${ }^{1}$ Diriba Muleta $\mathbb{D}^{1},{ }^{1}$ Fassil Assefa, ${ }^{1}$ and Solomon Kiros ${ }^{2}$ \\ ${ }^{1}$ College of Natural Sciences, Addis Ababa University, Addis Ababa, Ethiopia \\ ${ }^{2}$ Addis Ababa Institute of Technology, Addis Ababa University, Addis Ababa, Ethiopia \\ Correspondence should be addressed to Diriba Muleta; dmuleta@gmail.com
}

Received 20 July 2020; Accepted 1 October 2020; Published 29 October 2020

Academic Editor: Manoj Kumar Solanki

Copyright (c) 2020 Alemayehu Getahun et al. This is an open access article distributed under the Creative Commons Attribution License, which permits unrestricted use, distribution, and reproduction in any medium, provided the original work is properly cited.

\begin{abstract}
Drought stress (DS) is the most impacting global phenomenon affecting the ecological balance of a particular habitat. The search for potential plant growth-promoting rhizobacteria (PGPR) capable of enhancing plant tolerance to drought stress is needed. Thus, this study was initiated to evaluate the effect of inoculating Acacia abyssinica seedlings with PGPR isolated from rhizosphere soil of Ethiopia to enhance DS tolerance. The strains were selected based on in vitro assays associated with tolerance to drought and other beneficial traits such as salinity, acidity, temperature, heavy metal tolerances, biofilm formation, and exopolysaccharide (EPS) production. The strains with the best DS tolerance ability were selected for the greenhouse trials with acacia plants. The results indicate that out of 73 strains, 10 (14\%) were completely tolerant to $40 \%$ polyethylene glycol. Moreover, $37 \%$ of the strains were strong biofilm producers, while $66(90.41 \%)$ were EPS producers with a better production in the medium containing sucrose at $28 \pm 2^{\circ} \mathrm{C}$ and $\mathrm{pH} 7 \pm 0.2$. Strains PS-16 and RS-79 showed tolerance to $11 \% \mathrm{NaCl}$. All the strains were able to grow in wider ranges of $\mathrm{pH}(4-10)$ and temperature $\left(15-45^{\circ} \mathrm{C}\right)$ and had high tolerance to heavy metals. The inoculated bacterial strains significantly $(p \leq 0.05)$ increased root and shoot length and dry biomass of acacia plants. One of the strains identified as $P$. fluorescens strain FB-49 was outstanding in enhancing DS tolerance compared to the single inoculants and comparable to consortia. Stresstolerant PGPR could be used to enhance acacia DS tolerance after testing other phytobeneficial traits.
\end{abstract}

\section{Introduction}

Nowadays, the world has been terrified by global climate change scenarios. The scarcity of water is amongst a problem seen in the world which will drive the severity of drought episodes [1]. Degrading environment, rising population, and increased demand for resources affect severely ecological stability [2]. Action is needed to face the global threats arising from the effects of climate change, which could increase episodes of drought, salinity, toxicity by heavy metals, soil acidity, and extreme temperatures [3]. Drought stress (DS) is the most impacting phenomena that affects ecological integrity and ultimately results in degraded habitats with poor and/or no productivity [4]. It is estimated that drought covers approximately $41 \%$ of earth's land surface [5] and threatens more than 50\% of arable lands and causes a 50\% loss in crop yields, social, economic crisis, and environmental impacts [6]. Drought increases the demand for irrigation, which already comprises $70 \%$ of global water consumption [7]. Plants have evolved different mechanisms to mitigate DS that include a series of molecular, cellular, and physiological adaptations [8,9]. All DS-associated problems result in loss of soil microbial diversity, soil fertility, and aggravate competition for nutrients. These call for urgent intervention measures using drought-tolerant microbes as eco-friendly approaches [10]. Hence, integrating drought-tolerant beneficial microbes as a component of ecological systems to enhance plant drought tolerance might represent an interesting strategy. At the moment, efforts have been focused on harnessing the potential of 
phytobeneficial soil microbes to enhance environmental rehabilitation to combat the negative impacts of drought [11]. The positive influence of PGPR on conferring resistance to DS in many crops and trees has been reported [12]. Also, the production of biofilms and exopolysaccharides provides remarkable protection from external stress, decreases microbial competition, gives protecting effects to the host plants, and increases soil aggregation [13].

Numerous studies have documented the potential of many PGPR genera including Klebsiella, Pseudomonas, Acinetobacter, Paenibacillus, and Bacillus in enhancing plant stress tolerance in dryland areas [14, 15]. PGPR can enhance plant stress tolerance by an array of mechanisms that encompass the production of ACC deaminase [16], regulation of the hormonal balance of cytokinins [16], gibberellins [17], EPS [18], and microbial biofilm formation for protection from external stresses [13]. Screening for stress tolerance is an important parameter while selecting bacterial strains for the development of biofertilizers since the performance of PGPR is constrained by environmental stresses including temperature, desiccation, $\mathrm{pH}$, alkalinity/acidity, and salinity in the soil [19]. Due to their multiple traits, the search for suitable and rhizosphere competent PGPR becomes interesting and can be used as inoculants for biofertilization and biocontrol purposes in agriculture, forestry, and environmental rehabilitation. Acacia is highly used for conserving and improving degraded soils and landscapes. Acacia senegal is a key component of traditional agroforestry and a valuable tree species for restoration of soil fertility [20]. It is also used as belt rehabilitation at Dilling area (South Kordofan) in solving the problems of the traditional agricultural limited land [21]. Therefore, the selection of stress-tolerant bacterial strains might be critical for improving the field performance of diverse crops including woody plants. Hence, this work aimed to identify and characterize PGPR isolates that could enhance stress tolerance by promoting the growth of acacia seedlings.

\section{Materials and Methods}

2.1. Rhizobacteria Growth Conditions and Identification. Acacia and Juniperus rhizosphere soil samples were collected from degraded soil of north Shewa Zone, Oromia National Regional State, Ethiopia. It is located at $9^{\circ} 45^{\prime} 57^{\prime \prime} \mathrm{N}$ and $38^{\circ}$ $42^{\prime} 06^{\prime \prime} \mathrm{E}$, and the soil is characterized as sandy clay loam [22]. Soil samples were processed within $24 \mathrm{~h}$, and a tenfold serial dilution was made using sterilized distilled water. Primary isolations were done on Nutrient and King's B agar (both from Himedia). From an appropriate dilution factor, $100 \mu \mathrm{L}$ of the suspension was plated on Nutrient and King's $\mathrm{B}$ agar and incubated at $28 \pm 2^{\circ} \mathrm{C}$ for $24-48 \mathrm{~h}$ [23]. Tryptic Soy Agar (TSA, Himedia) was used for the screening purpose. Since water is the limiting factor in the study area, drought stress (DS) tolerance was taken as a baseline parameter and other plant growth-promoting (PGP) traits to select the potential strains were considered.

A total of 80 PGPR isolates with promising phytobeneficial traits and DS tolerance were selected. Since 7 isolates showed poor gel quality with very short base pair sequences, the number is further reduced to 73 . Firstly, the bacterial DNA was extracted and isolated using the DNeasy Blood \& Tissue kit (QIAGEN ${ }^{\circledR}$, Germany). The 16S rRNA genes were amplified using universal primers fD1 (forward) and $\mathrm{rD} 1$ (reverse). Primers used for gene amplification had the following sequences: fD1 (5'-AGAGTTTGATCCTGGCTCAG-3 $\left.{ }^{\prime}\right)$ and $\mathrm{rD} 1{ }^{\prime}\left(5^{\prime}\right.$-AAGGAGGTGATC CAGCC-3') [24]. The PCR products were purified using PureLink ${ }^{\circledR}$ Quick PCR Purification Kit and separated in a 1.5\% agarose gel to be examined under a UV illuminator (Locus Biotechnology L-Pix, Brazil) [25]. The PCR condition was set at initial denaturation at $95^{\circ} \mathrm{C}$ for $2 \mathrm{~min}$, denaturation at $94^{\circ} \mathrm{C}$ for $15 \mathrm{sec}$, annealing at $55^{\circ} \mathrm{C}$ for $45 \mathrm{sec}$, elongation at $72^{\circ} \mathrm{C}$ for $2 \mathrm{~min}$, and final elongation at $72^{\circ} \mathrm{C}$ for $5 \mathrm{~min}$. Finally, the PCR products were eluted and sequenced using 3500XL Genetic Analyzer (Hitachi, Applied Biosystems, Londrina, Brazil) with the incorporation of dideoxynucleosides (dd NTPs) into the reaction mixture. The sequence was done in Brazil, Londrina, and the sequence data was edited with Bionumeric 3.2 version [26]. Sequences were further analyzed using BLAST software of the National Center of Biotechnology Information (NCBI) website. Phylogenetic analysis of partial $16 \mathrm{~S}$ rRNA gene sequences was done using the Mega 7 software version 7.0.2 [27].

2.2. Screening Drought Stress (DS) Tolerance of PGPR. All the 80 isolates were tested for in vitro drought tolerance and plant growth-promoting traits. Osmotic stress was tested by adding $40 \%$ of polyethylene glycol-6000 (PEG) (400 g/L to Tryptic Soya Broth (TSB) g/L: pancreatic digest of casein 17; a peptic digest of soya bean meal 3 ; sodium chloride 5 ; dextrose 2.5 ; and dibasic potassium phosphate 2.5). A $1 \mathrm{~mL}$ of the bacterial culture at the concentration of $1 \times 10^{7} \mathrm{CFU} / \mathrm{mL}$ was estimated by optical density (OD) at $600 \mathrm{~nm}$ to be used as initial inoculum and added to the test tubes containing $10 \mathrm{~mL}$ of TSB amended with PEG 6000 to adjust the osmotic pressure at 1.76 Mega Pascal (MPa). The inoculated tubes were incubated at $28 \pm 2^{\circ} \mathrm{C}$ for $24 \mathrm{~h}$, and $\mathrm{OD}$ was recorded after 3 days. The OD values of drought tolerance were determined as follows: completely sensitive $\mathrm{OD}<0.3$; sensitive $\mathrm{OD}=(0.3-0.39)$; tolerant $\mathrm{OD}=(0.4-0.5)$, and completely tolerant $\mathrm{OD}>0.5[28]$.

\subsection{Qualitative Assay for Biofilm Detection}

2.3.1. Plate Method (PM). Mucoid nature of the bacterial colonies was observed after growth on Congo red agar (CRA) medium composed of $(\mathrm{g} / \mathrm{L})$ : brain heart infusion broth, 37; sucrose, 5, agar, 10; Congo red dye, 0.8 [29]. Eighteen-hour-old bacterial cultures were streaked on the CRA plates and incubated at $28 \pm 2^{\circ} \mathrm{C}$ for $24-48 \mathrm{~h}$ and observed for colony color. Black colonies with a dry crystalline consistency indicate biofilm production [30].

2.3.2. Tube Method (TM). Biofilm formation ability was observed by its adherence capacity to the walls of culture tubes [30]. A loopfull of each bacterial strain grown on TSB plates for $24 \mathrm{~h}$ was inoculated into $10 \mathrm{~mL}$ of nutrient broth 
with different $\mathrm{NaCl}$ concentrations (100 and $150 \mathrm{mM}$ which is used to show enhanced absorbance) in test tubes followed by shaking at $95 \mathrm{rpm}$ for $24-48 \mathrm{~h}$. The culture medium with bacteria was discarded, and the tubes were washed with $3 \mathrm{~mL}$ of $1 \mathrm{X}$ phosphate-buffered saline (PBS) of $\mathrm{pH} 7$. A $3 \mathrm{~mL}$ of $2 \%$ crystal violet solution was added and left for $15 \mathrm{~min}$. Tubes were then washed with sterile water and allowed to dry, and the tubes were visually observed for the presence of biofilms rings on the inner walls of the test tubes. Tubes then received $1.5 \mathrm{~mL}$ of $33 \%$ glacial acetic acid and mixed gently to measure OD at $570 \mathrm{~nm}$. PBS served as control. Biofilm formation in tubes was detected when a visible film (ring) lined the wall and the bottom of the tubes [31].

2.4. Exopolysaccharide Production. The qualitative determination of exopolysaccharide production was performed according to Paulo et al. [32]. Discs of sterile filter paper $(5 \mathrm{~mm})$ which were inoculated with $4 \mu \mathrm{L}$ of each isolate placed in Petri dishes containing nutrient agar medium g/L: (peptone 5; sodium chloride 5; beef extract 1.5; yeast extract 1.5 and agar 15) for the production of EPS test. This was evaluated by the size of the halo produced with its slime appearance. The production of EPS was confirmed by mixing a portion of the mucoid substance in $2 \mathrm{~mL}$ of chilled absolute ethanol, where the formation of a precipitate indicates the presence of EPS [32]. Similarly, each isolate was cultured at $28 \pm 2^{\circ} \mathrm{C}$ but varying the type of sugar (sucrose, glucose or lactose) each at $10 \mathrm{~g} / \mathrm{L}$ concentrations and the $\mathrm{pH}$ $(5.5 \pm 0.2$ and $7.5 \pm 0.2)$. After $48 \mathrm{~h}$ of growth, EPS production was evaluated based on the mucoid nature of growth around $5 \mathrm{~mm}$ discs.

2.5. Growth and Ecophysiological Characterization. For each biochemical and physiological tests, growth was determined by reading OD at $600 \mathrm{~nm}$ in nutrient broth $(\mathrm{g} / \mathrm{L})$ : peptone, 5 ; $\mathrm{NaCl}, 5$; beef extract, 1.5; yeast extract, 1.5. In all cases of tolerance measurements, the viability of the isolates was checked by streaking on TSA immediately following the OD reading and incubated at $28 \pm 2{ }^{\circ} \mathrm{C}$ for 24 to 48 days to confirm bacterial growth [33].

2.5.1. Salt, $p H$, Temperature, and Heavy Metal Tolerance. Tolerance to salinity was evaluated on TSA medium containing $1 \%, 3 \%, 5 \%, 7 \%, 9 \%$, and $11 \%(\mathrm{w} / \mathrm{v}) \mathrm{NaCl}[34]$. $\mathrm{pH}$ tolerance was tested in nutrient broth by adjusting the $\mathrm{pH}$ to $4,5,6,8$, and 10 with either $1 \mathrm{~N} \mathrm{NaOH}$ or $\mathrm{HCl}$ [35]. Temperature tolerance was evaluated by growing bacterial cultures in TSA at $4^{\circ} \mathrm{C}, 15^{\circ} \mathrm{C}, 25^{\circ} \mathrm{C}, 35^{\circ} \mathrm{C}, 40^{\circ} \mathrm{C}, 45^{\circ} \mathrm{C}$, and $50^{\circ} \mathrm{C}$. The agar dilution method was used to test the heavy metal (HM) tolerance of PGPR isolates [36]. A loopfull of 24-hour-old bacterial culture grown in the nutrient broth was streaked on Mueller-Hinton Agar (MHA) [37] plates amended with increasing concentrations $(50,100$, and $300 \mu \mathrm{g} / \mathrm{mL})$ of different heavy metals (lead from $\left(\mathrm{Pb}\left(\mathrm{CH}_{3} \mathrm{COO}\right)_{2} \cdot 3 \mathrm{H}_{2} \mathrm{O}\right.$, zinc from $\mathrm{ZnSO}_{4} .5 \mathrm{H}_{2} \mathrm{O}$, copper from $\mathrm{CuCl}_{2} \cdot 2 \mathrm{H}_{2} \mathrm{O}$, manganese from $\mathrm{MnSO}_{4} \cdot 4 \mathrm{H}_{2} \mathrm{O}$, and iron from $\mathrm{FeSO}_{4} \cdot 6 \mathrm{H}_{2} \mathrm{O}$ ). Plates were incubated at $28 \pm 2^{\circ} \mathrm{C}$ for $24 \mathrm{~h}$ and examined visually for the presence or absence of growth where the presence of growth was recorded as resistance/tolerance (R) and the absence of growth was recorded as susceptible (S). Unamended Mueller-Hinton Agar plates were used as controls to evaluate tolerance [38].

2.6. Greenhouse Experimental Trials. Pot trials were performed under greenhouse conditions at the Department of Microbial, Cellular, and Molecular Biology, Addis Ababa University. It was done to evaluate the potential of PGPR strains based on phytobeneficial traits exhibited for drought stress experiments using $A$. abyssinica plants. The seeds were collected from the highland region of Ethiopia and were scarified with concentrated $\mathrm{H}_{2} \mathrm{SO}_{4}$ in flasks to break seed dormancy. The flasks were swirled occasionally over 25-35 minutes [39]. Eight seeds were kept in equidistance position in sterilized Petri plates containing sterile moist filter paper and cotton for 7 days for germination [40]. After seeds germinated, four seedlings were transplanted into sterile plastic pots $(20 \times 15 \mathrm{~cm})$ filled with $3 \mathrm{~kg}$ sandy clay loam soil autoclaved for $1 \mathrm{~h}$. Plants were kept in well-watered conditions and fertilized with half-strength Hoagland solution each week to obtain nutrients at a free access rate for 60 days [41]. Plants were inoculated during transplanting and 7 days intervals after transplantation with $15 \mathrm{~mL}$ test strains $\left(10^{8} \mathrm{CFU} / \mathrm{mL}\right)$ for 60 days. After 60 days of growth, plants were regularly watered to maintain $20 \%$ moisture by measuring the weight of pots every two days. The experiment was performed with a completely randomized design (CRD) and replicated three times. Plants were harvested after 2 weeks of water suppression, and data on root length, shoot length, and root and shoot dry biomass were recorded [42].

2.7. Data Analysis. Analysis of variance (ANOVA) was used to test for significant differences of measurements of each bioassay, whereas Duncan's multiple range test (DMRT) was employed to show significant differences among diverse treatments (mean separation) at $p \leq 0.05$. Values are presented as mean \pm standard deviation (SD). All the statistical analyses were performed using the Statistical Analysis System (SAS) version 9.0 software package [27]. All phylogenetic analyses were performed with the software MEGA 7 [43].

\section{Results}

3.1. Microorganism Isolation and Identification. Eighty rhizobacterial strains were isolated from highly degraded soil of Ethiopia. But, 7 isolates were never sequenced, and 73 isolates were used for our purposes. Twenty-two isolates showed supreme drought tolerance. Of these, 10 completely drought-tolerant (CT) strains were used for plant growth promotion experiments in the greenhouse. The relationship among them with the closest species is shown in Figure 1 and Table 1. 


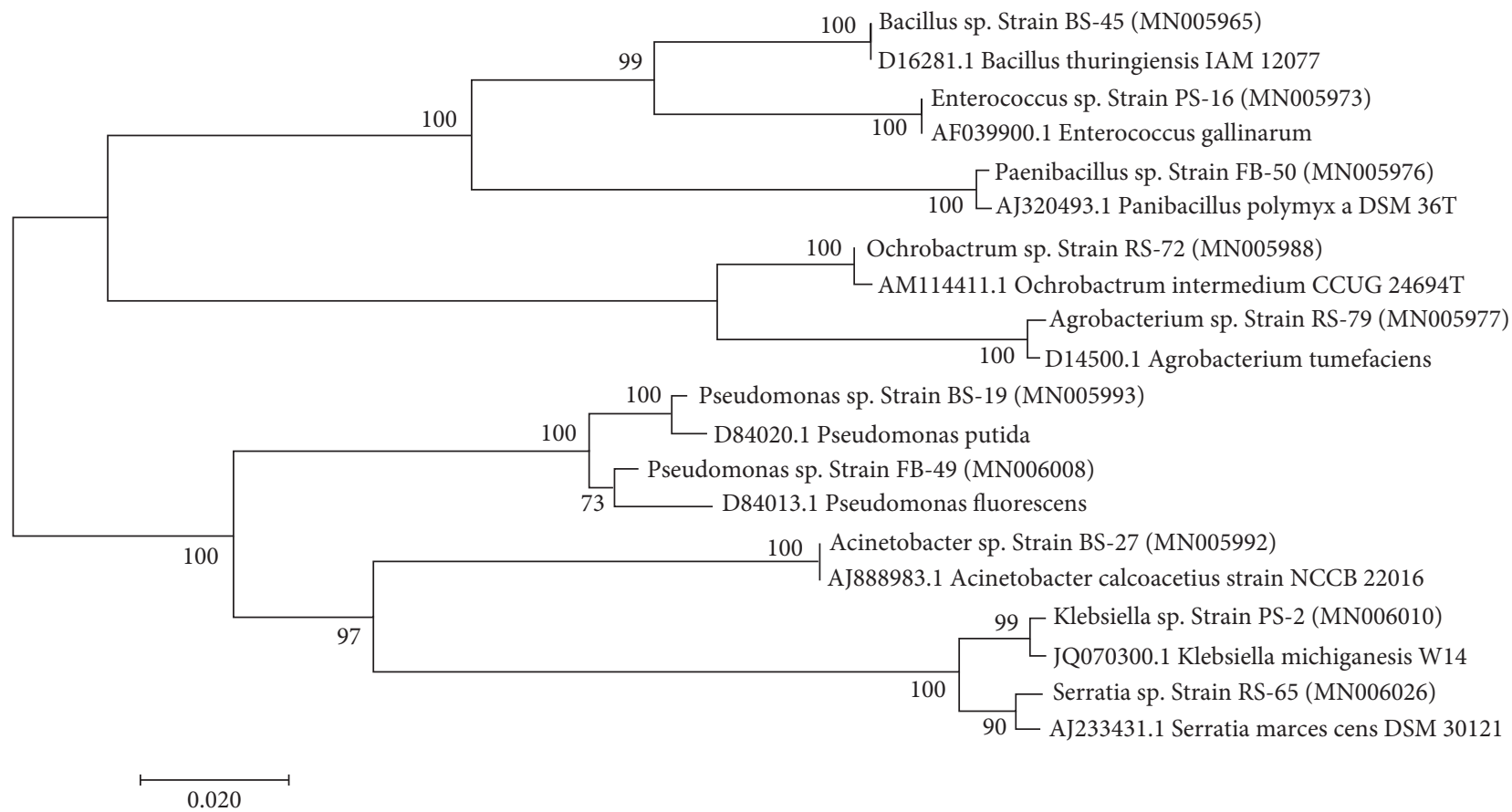

FIGURE 1: The phylogenetic relationship of top ten drought-tolerant strains with closest species. Accession numbers are indicated in brackets with bold text.

TABLE 1: In vitro top drought stress-tolerant PGPR isolates and the closest species identity based on the 16S rRNA gene sequence analysis.

\begin{tabular}{|c|c|c|c|c|c|}
\hline Isolate code & Closest relatives & Best match ID (NCBI) & Query cover (\%) & $\%$ Similarity & Gene bank accessions \\
\hline BS-45 & Bacillus thuringiensis & CP021436.1 & 100 & 100 & MN005965 \\
\hline PS-16 & Enterococcus gallinarum & JF915769.1 & 99 & 99 & MN005973 \\
\hline BS-51 & Paenibacillus polymyxa & СР006872.1 & 98 & 100 & MN005974 \\
\hline FB-50 & Paenibacillus polymyxa & CP025957.1 & 100 & 100 & MN005976 \\
\hline RS-79 & Agrobacterium tumefaciens & СР033032.1 & 100 & 99 & MN005977 \\
\hline RS-58 & Ochrobactrum intermedium & KC146415.1 & 100 & 100 & MN005978 \\
\hline RS-59 & Ochrobactrum intermedium & AJ242582.2 & 92 & 99 & MN005979 \\
\hline RS-66 & Ochrobactrum intermedium & AJ242582.2 & 99 & 99 & MN005982 \\
\hline RS-72 & Ochrobactrum intermedium & KC146415.1 & 100 & 100 & MN005988 \\
\hline BS-27 & Acinetobacter calcoaceticus & KC257031.1 & 99 & 99 & MN005992 \\
\hline BS-19 & Pseudomonas putida & СР025262.1 & 99 & 99 & MN005993 \\
\hline BS-26 & Pseudomonas plecoglossicida & MF281997.1 & 100 & 99 & MN005997 \\
\hline BS-44 & Pseudomonas fulva & СР014025.1 & 100 & 99 & MN006005 \\
\hline BS-53 & Pseudomonas fulva & СР014025.1 & 100 & 99 & MN006006 \\
\hline FB-49 & Pseudomonas fluorescens & KY228953.1 & 100 & 100 & MN006008 \\
\hline PS-2 & Klebsiella michiganensis & СР033824.1 & 100 & 99 & MN006010 \\
\hline PS-3 & Klebsiella oxytoca & СР033824.1 & 99 & 99 & MN006011 \\
\hline BS-46 & Morganella morganii & СР032295.1 & 99 & 99 & MN006012 \\
\hline PS-6 & Morganella morganii & СР032295.1 & 100 & 99 & MN006013 \\
\hline PS-14 & Morganella morganii & СР032295.1 & 100 & 99 & MN006017 \\
\hline RS-65 & Serratia marcescens & СР021164.1 & 99 & 99 & MN006026 \\
\hline RS-54 & Serratia fonticola & LR134492.1 & 100 & 99 & MN006030 \\
\hline
\end{tabular}

\subsection{Tolerance of Rhizobacteria to Stresses}

3.2.1. Drought Stress. From the 73 tested bacterial isolates, $10(14 \%)$ were categorized as completely tolerant (CT) to DS with OD $>0.5$ followed by $12(16 \%)$ in the class of tolerant (T) with OD that ranged from 0.40 to 0.47 and $15(21 \%)$ as sensitive (S) with OD 0.3 to 0.36 , and the remaining 36 (49\%) grouped as completely sensitive (CS) with OD that ranged from 0.06 to 0.25 (Figure 2).

Out of 73, 10 isolates showing completely drought tolerant (CT), and multiple PGP traits were selected for other stress assays and greenhouse experiments. The mean drought tolerance of each isolate is shown in Table 2 . The highest drought tolerance (0.64) OD value was 


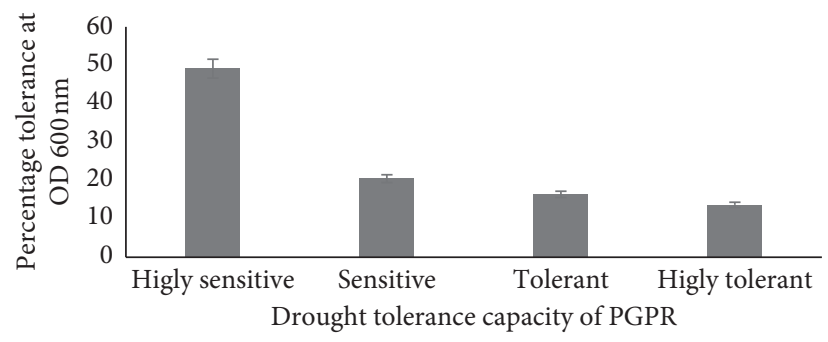

FIGURE 2: The percentage of drought tolerance classification of PGPR recovered from degraded soil.

TABLE 2: In vitro features of the strains selected based on water stress-tolerant potentials.

\begin{tabular}{lcccc}
\hline S. No. & Isolate code & Closest relatives & Mean \pm SD $600 \mathrm{~nm}$ OD $(n=3)$ & Tolerance levels \\
\hline 1 & BS-45 & Bacillus thuringiensis & $0.53 \pm 0.12$ & CT \\
2 & PS-16 & Enterococcus gallinarum & $0.54 \pm 0.17$ & CT \\
3 & FB-50 & Paenibacillus polymyxa & $0.51 \pm 0.16$ & CT \\
4 & RS-79 & Agrobacterium tumefaciens & $0.57 \pm 0.20$ & CT \\
5 & RS-72 & Ochrobactrum intermedium & $0.52 \pm 0.22$ & CT \\
6 & BS-27 & Acinetobacter calcoaceticus & $0.59 \pm 0.19$ & CT \\
7 & BS-19 & Pseudomonas putida & $0.60 \pm 0.12$ & CT \\
8 & FB-49 & Pseudomonas fluorescens & $0.64 \pm 0.15$ & CT \\
9 & PS-2 & Klebsiella michiganensis & $0.50 \pm 0.17$ & CT \\
10 & RS-65 & Serratia marcescens & $0.55 \pm 0.15$ & CT \\
\hline
\end{tabular}

Values are mean \pm standard deviation.

observed in $P$. fluorescens strain FB-49 followed by P. putida strain FB-49 with OD value 0.60.

3.3. Qualitative Biofilm Detection. Most of the isolates produced black colonies on CRA after 24-48 h (Supplementary Figure S1). In the tube method, the formation of visible thick film inside the wall of tubes and their bottom (supplementary Figure S2). Out of 73, 27 (37\%) isolates were strong biofilm producers, while $49 \%$ were moderate, and the remaining (14\%) were weak or nonbiofilm producers using test tubes method (TM) at $150 \mathrm{mM} \mathrm{NaCl}$. By using TM but with different $\mathrm{NaCl}$ concentrations (100 mM), 10\%, 55\%, and $34 \%$ were perceived as strong, moderate, and weak biofilm-producing PGPR isolates, respectively (Figure 3).

The results indicated that the activity of biofilm formation was increased with increasing $\mathrm{NaCl}$ concentration. The highest significant increase was recorded in BS-19 (0.805 OD) and FB-49 (0.765 OD) isolates treated with $150 \mathrm{mM}$ $\mathrm{NaCl}$, while the lowest was observed in isolate PS-2 (0.39 OD) (Figure 4).

3.4. Exopolysaccharide Production. The production of EPS was determined based on both mucoid colony production on culture medium and precipitate formation in chilled ethanol in a test tube (Supplementary Figures S3). Of the 73 PGPRs evaluated for the EPS production, 66 (90.41\%) were positive, while the remaining $7(9.59 \%)$ were negative. The medium containing sucrose induced a higher number of isolates to produce EPS, with $41(48.2 \%)$ positive results, most of which $(65.85 \%)$ were at $28 \pm 2^{\circ} \mathrm{C}$ and $\mathrm{pH} 7 \pm 0.2$. The second-highest number of EPS-producing isolates was

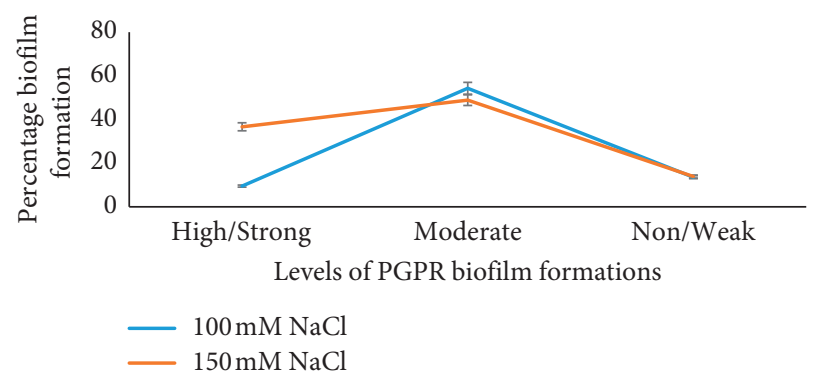

FIgURE 3: Classification and comparisons of bacterial biofilm formation abilities at $100 \mathrm{mM}$ and $\mathrm{NaCl} 150 \mathrm{mM} \mathrm{NaCl}$ concentrations.

found in the medium containing glucose, with 26 (30.58\%) positive results, of which $61.53 \%$ were under the same conditions of $\mathrm{pH}$ and temperature that tested best with sucrose. Moreover, the medium containing lactose resulted in $18(21.17 \%)$ positive results, with $61 \%$, also under the same conditions of $\mathrm{pH}$ and temperature of other media (data not shown).

\subsection{Salt, $p H$, Temperature, and Heavy Metal Tolerance}

3.5.1. Tolerance at Different $\mathrm{NaCl}$ Concentrations. Our results indicate that PGPR strains could grow over a wide range of $\mathrm{NaCl}$ (1 to $11 \%$ ) concentrations (Figure 5). Isolates PS-16 and RS-79 showed the highest $\mathrm{NaCl}$ tolerance followed by FB-49 and FB-50 with 9\%. BS-19 was identified as the least tolerant. However, higher $\mathrm{NaCl}$ concentration led to a drastic reduction in the growth of bacterial isolates. 


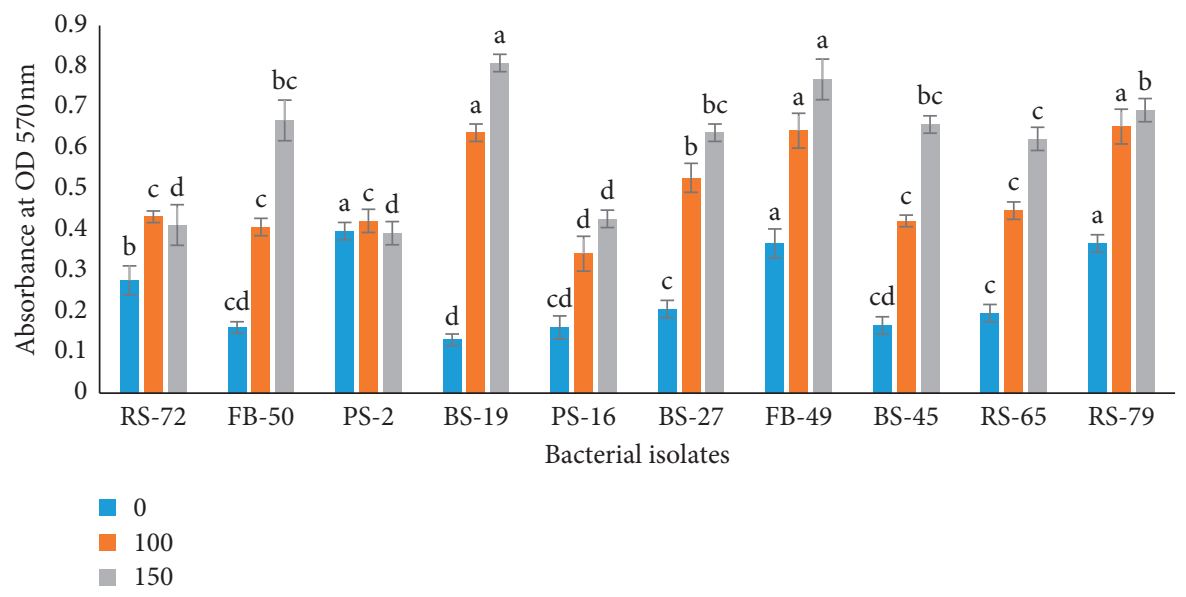

FIGURE 4: The optical density (OD at $570 \mathrm{~nm}$ ) as the measure of the activity of biofilm formation for PGPR isolates with three NaCl (0, 100 , and $150 \mathrm{mM}$ ) concentrations.

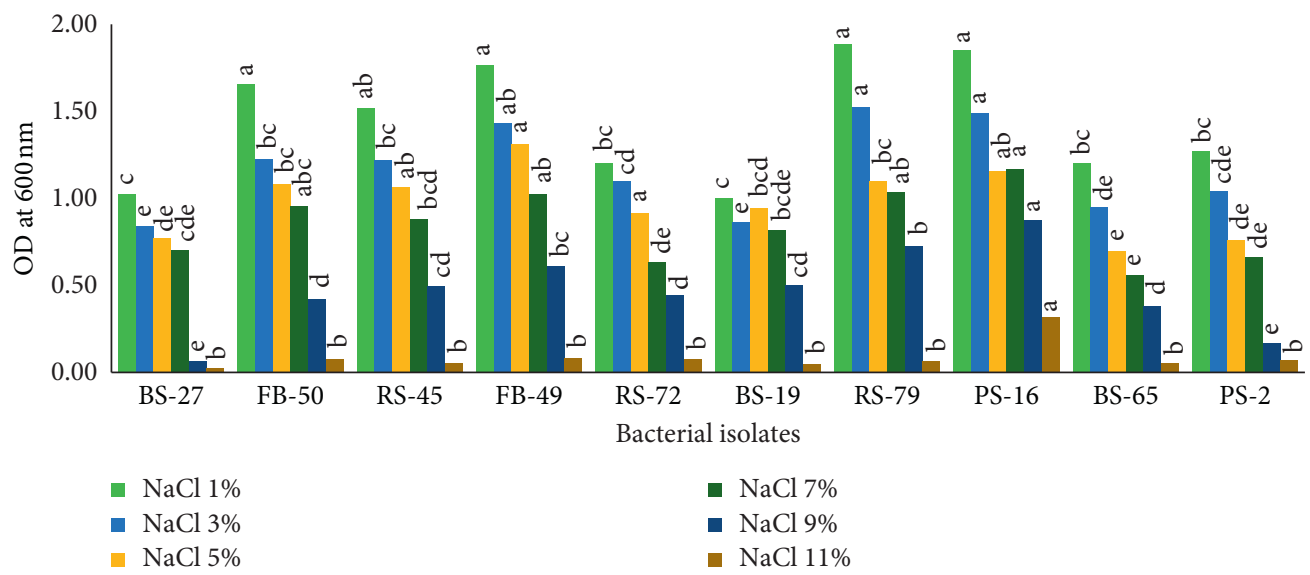

Figure 5: Effect of $\mathrm{NaCl}$ concentration on the growth of ten selected PGPR strains. Bars represent mean \pm SD of three replicates. Treatments followed by different letters indicate significant difference over control using Duncan's multiple range test $(p \leq 0.05)(n=3)$.

3.5.2. Growth at Different $p H$ Ranges. In our study, a wide $\mathrm{pH}$ range tolerance was confirmed in PGPR ability to survive both in acidic and alkaline soils. Among different levels of $\mathrm{pH}$ tested, all the isolates showed maximum growth at $\mathrm{pH} 7$ followed by $\mathrm{pH} 10$ and $\mathrm{pH}$ 9, while the minimum growth of most of the bacterial isolates was observed at $\mathrm{pH} 4$. Isolates RS-79, FB-49, BS-65, and PS-2 grew better on agar medium of $\mathrm{pH} 5$ and FB-49 and RS-79 at pH 4 (Table 3).

3.5.3. Response to Different Temperatures. All the 73 isolates were able to grow within a broad range of temperature $\left(20^{\circ} \mathrm{C}\right.$ to $45^{\circ} \mathrm{C}$ ) but grew not at $4^{\circ} \mathrm{C}$ or $50^{\circ} \mathrm{C}$ as confirmed on solid agar medium. Maximum growth was achieved at $25^{\circ} \mathrm{C}, 35^{\circ} \mathrm{C}$, and $40^{\circ} \mathrm{C}$ but lower at $15^{\circ} \mathrm{C}$ and $45^{\circ} \mathrm{C}$ (Table 4). Four (FB-50, RS-45, FB-49, and RS-79) isolates exhibited remarkable tolerance to high temperature $\left(45^{\circ} \mathrm{C}\right)$ followed by BS- 19 .

3.5.4. Tolerance of PGPR to Heavy Metals (HMs). Many isolates were tolerant to various concentrations of heavy metals tested (Figure 6). All isolates (100\%) showed resistance to $50 \mu \mathrm{g} / \mathrm{mL}$ of $\mathrm{Fe}, \mathrm{Mn}, \mathrm{Cu}, \mathrm{Zn}$, and $\mathrm{Pb}$, whereas almost all isolates were able to grow on the medium containing 100 $\mu \mathrm{g} / \mathrm{mL}$ of Fe and $\mathrm{Mn}$. However, fewer isolates grew on the medium containing the same concentration of $\mathrm{Zn}$ (77\% of the isolates), $\mathrm{Pb}(73 \%)$, and $\mathrm{Cu}(67 \%)$, respectively. Moreover, bacteria growth significantly declined $(p \leq 0.05)$ to $32 \%-44$ at $300 \mu \mathrm{g} / \mathrm{mL}$ increase in concentrations of the heavy metals, except Fe (Table 5).

3.6. Drought Stress Enhancements in Acacia under Greenhouse Trial. Inoculation with bacterial consortia had a significant $(p \leq 0.05)$ effect on plant biomass $57.3 \mathrm{~cm}, 19.3 \mathrm{~cm}, 2.1 \mathrm{~g}$, $0.8 \mathrm{~g}$, and 16.7 in $\mathrm{SH}, \mathrm{RL}, \mathrm{SDW}$, and RDW and number of leaves per plant, respectively, compared to noninoculated control. Among single inoculants, P. fluorescens and $P$. polymyxa showed the maximum $A$. abyssinica performance under drought conditions. Klebsiella michiganensis showed the least drought stress improvement $(38.7 \mathrm{~cm})$ in $\mathrm{SH}$ compared to the other singly inoculated plants but performed better compared to noninoculated control treatment (Table 6). The performance of acacia in the greenhouse trials is shown in Figure 7. 
TABLE 3: Growth determined at OD $600 \mathrm{~nm}$ of selected PGPR isolates at varying $\mathrm{pH}$ ranges.

\begin{tabular}{lccccc}
\hline Isolate & $\mathrm{pH} 4$ & $\mathrm{pH}$ & $\mathrm{pH}$ & $\mathrm{pH9}$ & $\mathrm{pH} 10$ \\
\hline BS-27 & $0.12 \pm 0.01^{\mathrm{c}}$ & $0.44 \pm 0.04^{\mathrm{cd}}$ & $1.26 \pm 0.21^{\mathrm{abcd}}$ & $0.68 \pm 0.02^{\mathrm{bc}}$ & $1.13 \pm 0.09^{\mathrm{abc}}$ \\
FB-50 & $0.14 \pm 0.02^{\mathrm{bc}}$ & $0.43 \pm 0.05^{\mathrm{cd}}$ & $1.32 \pm 0.19^{\mathrm{abcd}}$ & $0.4 \pm 0.08^{\mathrm{def}}$ & $1.11 \pm 0.12^{\mathrm{abc}}$ \\
RS-45 & $0.08 \pm 0.01^{\mathrm{c}}$ & $0.15 \pm 0.05^{\mathrm{e}}$ & $1.39 \pm 0.09^{\mathrm{ab}}$ & $0.3 \pm 0.05^{\mathrm{ef}}$ & $1.17 \pm 0.11^{\mathrm{ab}}$ \\
FB-49 & $0.26 \pm 0.04^{\mathrm{a}}$ & $0.67 \pm 0.09^{\mathrm{bc}}$ & $1.46 \pm 0.11^{\mathrm{a}}$ & $0.85 \pm 0.14^{\mathrm{ab}}$ & $1.32 \pm 0.23^{\mathrm{a}}$ \\
RS-72 & $0.12 \pm 0.04^{\mathrm{c}}$ & $0.24 \pm 0.05^{\mathrm{de}}$ & $1.05 \pm 0.04^{\mathrm{b}}$ & $0.42 \pm 0.09^{\mathrm{ef}}$ & $0.97 \pm 0.07^{\mathrm{bcd}}$ \\
BS-19 & $0.11 \pm 0.02^{\mathrm{c}}$ & $0.14 \pm 0.06^{\mathrm{e}}$ & $1.11 \pm 0.10^{\mathrm{bcd}}$ & $0.26 \pm 0.06^{\mathrm{f}}$ & $0.80 \pm 0.11^{\mathrm{cd}}$ \\
RS-79 & $0.21 \pm 0.02^{\mathrm{ab}}$ & $0.84 \pm 0.06^{\mathrm{a}}$ & $1.20 \pm 0.14^{\mathrm{abcd}}$ & $0.51 \pm 0.15^{\mathrm{cde}}$ & $0.70 \pm 0.15^{\mathrm{d}}$ \\
PS-16 & $0.07 \pm 0.02^{\mathrm{c}}$ & $0.42 \pm 0.05^{\mathrm{cd}}$ & $1.39 \pm 0.06^{\mathrm{ab}}$ & $0.54 \pm 0.14^{\text {cde }}$ & $1.13 \pm 0.116^{\mathrm{abc}}$ \\
BS-65 & $0.09 \pm 0.02^{\mathrm{c}}$ & $0.63 \pm 0.05^{\mathrm{b}}$ & $1.09 \pm 0.10^{\mathrm{cd}}$ & $0.65 \pm 0.15^{\mathrm{bcd}}$ & $1.01 \pm 0.04 \mathrm{a}^{\mathrm{bcd}}$ \\
PS-2 & $0.06 \pm 0.03^{\mathrm{c}}$ & $0.49 \pm 0.08^{\mathrm{bc}}$ & $1.34 \pm 0.03^{\mathrm{abc}}$ & $0.93 \pm 0.05^{\mathrm{a}}$ & $1.18 \pm 0.03^{\mathrm{ab}}$ \\
\hline
\end{tabular}

Means with the same letter down the column are not significantly different with mean \pm SD, $n=3$.

TABLE 4: Effect of temperature on the growth of selected PGPR isolates OD readings at $600 \mathrm{~nm}$.

\begin{tabular}{lccccc}
\hline Isolates & Temp. $15^{\circ} \mathrm{C}$ & Temp. $25^{\circ} \mathrm{C}$ & Temp. $35^{\circ} \mathrm{C}$ & Temp. $40^{\circ} \mathrm{C}$ & Temp. $45^{\circ} \mathrm{C}$ \\
\hline BS-27 & $0.30 \pm 0.04^{\mathrm{a}}$ & $0.89 \pm 0.07^{\mathrm{ab}}$ & $1.13 \pm 0.04^{\mathrm{abc}}$ & $0.89 \pm 0.14^{\mathrm{abc}}$ & $0.55 \pm 0.05^{\mathrm{b}}$ \\
FB-50 & $0.25 \pm 0.07^{\mathrm{abc}}$ & $0.98 \pm 0.11^{\mathrm{ab}}$ & $1.16 \pm 0.02^{\mathrm{abc}}$ & $0.82 \pm 0.15^{\mathrm{bc}}$ & $1.01 \pm 0.09^{\mathrm{a}}$ \\
RS-45 & $0.19 \pm 0.04^{\mathrm{abc}}$ & $0.85 \pm 0.17^{\mathrm{ab}}$ & $0.87 \pm 0.05^{\mathrm{bc}}$ & $1.12 \pm 0.02^{\mathrm{abc}}$ & $0.95 \pm 0.11^{\mathrm{a}}$ \\
FB-49 & $0.26 \pm 0.05^{\mathrm{ab}}$ & $1.21 \pm 0.14^{\mathrm{a}}$ & $1.36 \pm 0.19^{\mathrm{ab}}$ & $1.10 \pm 0.12^{\mathrm{a}}$ & $0.94 \pm 0.14^{\mathrm{a}}$ \\
RS-72 & $0.16 \pm 0.01^{\mathrm{bc}}$ & $0.76 \pm 0.05^{\mathrm{b}}$ & $1.05 \pm 0.02^{\mathrm{c}}$ & $0.73 \pm 0.03^{\mathrm{c}}$ & $0.29 \pm 0.03^{\mathrm{b}}$ \\
BS-19 & $0.22 \pm 0.02^{\mathrm{abc}}$ & $0.93 \pm 0.07^{\mathrm{ab}}$ & $1.39 \pm 0.09^{\mathrm{a}}$ & $0.85 \pm 0.07^{\mathrm{abc}}$ & $0.53 \pm 0.05^{\mathrm{b}}$ \\
RS-79 & $0.21 \pm 0.04^{\mathrm{abc}}$ & $0.80 \pm 0.13^{\mathrm{b}}$ & $1.29 \pm 0.07^{\mathrm{abc}}$ & $0.73 \pm 0.05^{\mathrm{c}}$ & $0.55 \pm 0.03^{\mathrm{b}}$ \\
PS-16 & $0.17 \pm 0.02^{\mathrm{abc}}$ & $0.98 \pm 0.09^{\mathrm{ab}}$ & $1.13 \pm 0.07^{\mathrm{abc}}$ & $0.92 \pm 0.10^{\mathrm{abc}}$ & $0.45 \pm 0.07^{\mathrm{b}}$ \\
BS-65 & $0.21 \pm 0.03^{\mathrm{abc}}$ & $0.90 \pm 0.11^{\mathrm{ab}}$ & $1.15 \pm 0.09^{\mathrm{abc}}$ & $0.72 \pm 0.09^{\mathrm{c}}$ & $0.54 \pm 0.04^{\mathrm{b}}$ \\
PS-2 & $0.12 \pm 0.02^{\mathrm{c}}$ & $0.75 \pm 0.06^{\mathrm{b}}$ & $1.14 \pm 0.07^{\mathrm{abc}}$ & $1.07 \pm 0.06^{\mathrm{ab}}$ & $0.47 \pm 0.09^{\mathrm{b}}$ \\
\hline
\end{tabular}

Means with the same letter down the column are not significantly different. Mean \pm SD of three replicates using Duncan's multiple range test $(p \leq 0.05) n=3$. Temp $=$ temperature.

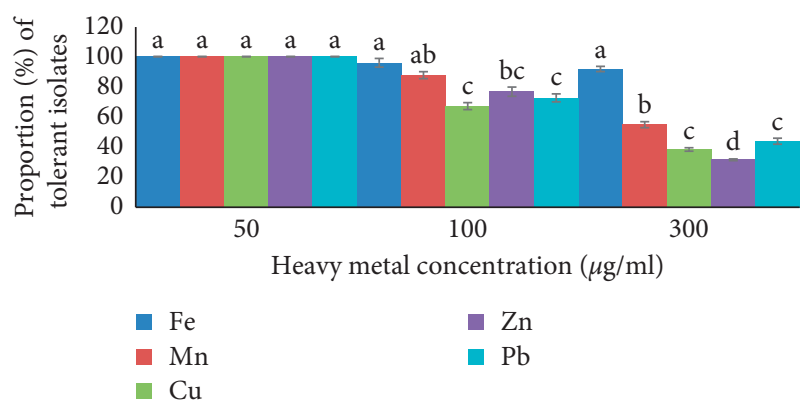

FIgURE 6: Tolerance of PGPR isolates to HM concentration. The different letters on the standard error (SD) bars indicate a significant difference using Duncan's multiple range test at $p \leq 0.05$. Values are means of three of replicates.

\section{Discussion}

In the present study, effective PGPR isolates that grew in medium with reduced water content is considered as drought tolerant. Because $30 \%$ of the bacterial isolates showed in vitro tolerance to $40 \%$ PEG. The tolerance is mainly associated with biofilm formation and EPS production potential of the isolates. This is an initial selection of bacterial isolates based on their ability to grow in medium and is an interesting approach for other stress-associated assays. This feature is very crucial for degraded land restoration under water-stressed conditions by inoculating such potential isolates. The variation in drought tolerance among bacteria may be related to specific adaptations and gained strain-specific traits. The bacteria reaching OD greater than 0.5 categorized as completely drought tolerant [28]. Also, drought-tolerant Rhizobium sp. survived with $45 \%$ of PEG-enhanced drought tolerance of sesbania [44]. In another trial, Pseudomonas spp. and Bacillus spp. with good plant growth-promoting ability survived $40.5 \%$ PEG concentration [45]. The mechanisms by which PGPR can survive and adapt to extreme drought conditions are associated with secretion of EPS [46, 47], biofilm formation [48, 49], and ACC (1-aminocyclopropane-1-carboxylate deaminase) production $[47,50]$ and induced systemic tolerance by bacterial compounds [51] and other phytobeneficial traits. Moreover, drought tolerance occurs on wheat root colonization with Paenibacillus spp. and Bacillus spp. that can boost plant survival under drought stress [52, 53].

In the present study, we observed a dramatic change in PGPR ability to form a biofilm in 100 and $150 \mathrm{mM} \mathrm{NaCl}$ concentration. The current finding indicates that the activity of biofilm formation was increased with increasing $\mathrm{NaCl}$ concentration. The formation of biofilm and exopolysaccharide kept the viability of bacterial cells under salt stress to protect them in the rhizosphere. This is due the higher ionic strengths that are known to reduce the repulsion between a bacterial cell and a material surface. Moreover, it is well known that salt stress induces biofilm formation [54]. Biofilm-producing cells are attached to biotic or abiotic 
TABLE 5: Heavy metal tolerance profile of ten potential PGPR strains at a varying concentration of HMs.

\begin{tabular}{|c|c|c|c|c|c|c|c|c|c|c|c|c|c|c|c|c|c|}
\hline \multirow{2}{*}{$\begin{array}{l}\text { S. } \\
\text { No. }\end{array}$} & \multirow[b]{2}{*}{ Isolates } & \multicolumn{16}{|c|}{ Tolerance $(\mu \mathrm{g} / \mathrm{ml})$} \\
\hline & & $\begin{array}{l}\mathrm{Fe} \\
50\end{array}$ & $\begin{array}{c}\mathrm{Fe} \\
100\end{array}$ & $\begin{array}{c}\mathrm{Fe} \\
300\end{array}$ & $\begin{array}{c}\mathrm{Mn} \\
50\end{array}$ & $\begin{array}{l}\mathrm{Mn} \\
100\end{array}$ & $\begin{array}{l}\mathrm{Mn} \\
300\end{array}$ & $\begin{array}{c}\mathrm{Cu} \\
50\end{array}$ & $\begin{array}{r}\mathrm{Cu} \\
100\end{array}$ & $\begin{array}{c}\mathrm{Cu} \\
300\end{array}$ & $\begin{array}{l}\mathrm{Zn} \\
50\end{array}$ & $\begin{array}{c}\mathrm{Zn} \\
100\end{array}$ & $\begin{array}{l}\mathrm{Zn} \\
300\end{array}$ & $\begin{array}{l}\mathrm{Pb} \\
50\end{array}$ & $\begin{array}{l}\mathrm{Pb} \\
100\end{array}$ & $\begin{array}{c}\mathrm{Pb} \\
300\end{array}$ & $\begin{array}{c}\% \\
(\mathrm{R})\end{array}$ \\
\hline 1 & $\begin{array}{l}\text { Bacillus thuringiensis } \\
\text { BS- } 45\end{array}$ & $\mathrm{~T}$ & $\mathrm{~T}$ & $\mathrm{~T}$ & $\mathrm{~T}$ & $\mathrm{~T}$ & $S$ & $\mathrm{~T}$ & $\mathrm{~T}$ & $\mathrm{~T}$ & $\mathrm{~T}$ & $\mathrm{~T}$ & $\mathrm{~T}$ & $\mathrm{~T}$ & $\mathrm{~T}$ & $\mathrm{~T}$ & 90 \\
\hline 2 & $\begin{array}{c}\text { Enterococcus } \\
\text { gallinarum PS-16 }\end{array}$ & $\mathrm{T}$ & $\mathrm{T}$ & $\mathrm{T}$ & $\mathrm{T}$ & $\mathrm{T}$ & $\mathrm{T}$ & $\mathrm{T}$ & $S$ & S & $\mathrm{T}$ & $\mathrm{T}$ & S & $\mathrm{T}$ & $\mathrm{T}$ & $\mathrm{T}$ & 70 \\
\hline 3 & $\begin{array}{c}\text { Paenibacillus polymyxa } \\
\text { FB-50 }\end{array}$ & $\mathrm{T}$ & $\mathrm{T}$ & $\mathrm{T}$ & $\mathrm{T}$ & $\mathrm{T}$ & $\mathrm{T}$ & $\mathrm{T}$ & $\mathrm{T}$ & $\mathrm{T}$ & $\mathrm{T}$ & $\mathrm{T}$ & $\mathrm{T}$ & $\mathrm{T}$ & $\mathrm{T}$ & $\mathrm{T}$ & 100 \\
\hline 4 & $\begin{array}{c}\text { Agrobacterium } \\
\text { tumefaciens } \text { RS-79 }\end{array}$ & $\mathrm{T}$ & $\mathrm{T}$ & $\mathrm{T}$ & $\mathrm{T}$ & $\mathrm{T}$ & $\mathrm{T}$ & $\mathrm{T}$ & $\mathrm{T}$ & S & $\mathrm{T}$ & $\mathrm{T}$ & S & $\mathrm{T}$ & $\mathrm{T}$ & $\mathrm{T}$ & 80 \\
\hline 5 & $\begin{array}{c}\text { Ochrobactrum } \\
\text { intermedium RS-72 }\end{array}$ & $\mathrm{T}$ & $\mathrm{T}$ & $\mathrm{T}$ & $\mathrm{T}$ & $\mathrm{T}$ & S & $\mathrm{T}$ & $\mathrm{T}$ & $\mathrm{T}$ & $\mathrm{T}$ & $\mathrm{S}$ & S & $\mathrm{T}$ & S & S & 50 \\
\hline 6 & $\begin{array}{c}\text { Acinetobacter } \\
\text { calcoaceticus BS-27 }\end{array}$ & $\mathrm{T}$ & $\mathrm{T}$ & $\mathrm{T}$ & $\mathrm{T}$ & $\mathrm{T}$ & $\mathrm{T}$ & $\mathrm{T}$ & $\mathrm{T}$ & $\mathrm{T}$ & $\mathrm{T}$ & $\mathrm{T}$ & $\mathrm{T}$ & $\mathrm{T}$ & $\mathrm{T}$ & $\mathrm{T}$ & 100 \\
\hline 7 & $\begin{array}{c}\text { Pseudomonas putida } \\
\text { BS-19 }\end{array}$ & $\mathrm{T}$ & $\mathrm{T}$ & $\mathrm{T}$ & $\mathrm{T}$ & $\mathrm{T}$ & $\mathrm{T}$ & $\mathrm{T}$ & $\mathrm{T}$ & $\mathrm{T}$ & $\mathrm{T}$ & $\mathrm{T}$ & $\mathrm{T}$ & $\mathrm{T}$ & $\mathrm{T}$ & $\mathrm{T}$ & 100 \\
\hline 8 & $\begin{array}{c}\text { Pseudomonas } \\
\text { fluorescens FB-49 }\end{array}$ & $\mathrm{T}$ & $\mathrm{T}$ & $\mathrm{T}$ & $\mathrm{T}$ & $\mathrm{T}$ & $\mathrm{T}$ & $\mathrm{T}$ & $\mathrm{T}$ & $\mathrm{T}$ & $\mathrm{T}$ & $\mathrm{T}$ & $\mathrm{T}$ & $\mathrm{T}$ & $\mathrm{T}$ & $\mathrm{T}$ & 100 \\
\hline 9 & $\begin{array}{c}\text { Klebsiella } \\
\text { michiganensis PS-2 }\end{array}$ & $\mathrm{T}$ & $\mathrm{T}$ & $\mathrm{T}$ & $\mathrm{T}$ & $\mathrm{T}$ & S & $\mathrm{T}$ & $\mathrm{T}$ & $\mathrm{T}$ & $\mathrm{T}$ & S & S & $\mathrm{T}$ & $\mathrm{T}$ & $\mathrm{T}$ & 70 \\
\hline \multirow[t]{3}{*}{10} & $\begin{array}{c}\text { Serratia marcescens } \\
\text { RS-65 }\end{array}$ & $\mathrm{T}$ & $\mathrm{T}$ & $\mathrm{T}$ & $\mathrm{T}$ & $\mathrm{T}$ & S & $\mathrm{T}$ & S & S & $\mathrm{T}$ & S & $\mathrm{S}$ & $\mathrm{T}$ & $\mathrm{T}$ & $\mathrm{T}$ & 50 \\
\hline & $\%(\mathrm{~T})$ & 100 & 100 & 100 & 100 & 100 & 70 & 100 & 80 & 70 & 100 & 70 & 60 & 100 & 90 & 90 & \\
\hline & $\%(\mathrm{~S})$ & $\mathbf{0}$ & $\mathbf{0}$ & $\mathbf{0}$ & & $\mathbf{0}$ & 30 & $\mathbf{0}$ & 20 & 30 & $\mathbf{0}$ & 30 & 40 & $\mathbf{0}$ & 10 & 10 & \\
\hline
\end{tabular}

$\mathrm{T}=$ tolerant and $\mathrm{S}=$ sensitive.

TABLE 6: Plant growth promotion in A. abyssinica treated with different PGPRs individually and consortium under control and drought stress conditions.

\begin{tabular}{|c|c|c|c|c|c|}
\hline Treatment & $\mathrm{SH}(\mathrm{cm}) /$ pot & $\mathrm{RL}(\mathrm{cm}) /$ pot & No. of leaves/pot & SDW (g)/pot & RDW (g)/pot \\
\hline Control & $38.3 \pm 2.9^{\mathrm{i}}$ & $10.0 \pm 2.6^{\mathrm{i}-\mathrm{k}}$ & $14.0 \pm 2.6^{\mathrm{f}-\mathrm{i}}$ & $0.9 \pm 0.2^{\mathrm{jk}}$ & $0.12 \pm 0.01^{\mathrm{jk}}$ \\
\hline Control + D & $31.7 \pm 2.1^{\mathrm{j}}$ & $7.0 \pm 2.6^{\mathrm{k}}$ & $9.3 \pm 1.5^{\mathrm{j}}$ & $0.6 \pm 0.1^{\mathrm{k}}$ & $0.1 \pm 0.02^{\mathrm{k}}$ \\
\hline BS-27 & $50.7 \pm 0.6^{\mathrm{d}}$ & $14.0 \pm 2^{\mathrm{f}-\mathrm{h}}$ & $17.3 \pm 1.2^{\mathrm{c}-\mathrm{e}}$ & $1.9 \pm 0.4^{\mathrm{b}-\mathrm{e}}$ & $0.4 \pm 0.06^{\mathrm{d}-\mathrm{i}}$ \\
\hline $\mathrm{BS}-27+\mathrm{D}$ & $43.3 \pm 1.5^{\mathrm{f}-\mathrm{h}}$ & $11.0 \pm 1^{\mathrm{h}-\mathrm{j}}$ & $11.0 \pm 2^{\mathrm{ij}}$ & $1.5 \pm 0.2^{\mathrm{e}-\mathrm{i}}$ & $0.3 \pm 0.04^{\mathrm{g}-\mathrm{j}}$ \\
\hline FB-50 & $52.0 \pm 2.6^{\mathrm{d}}$ & $17.7 \pm 1.5^{\mathrm{b}-\mathrm{e}}$ & $18.0 \pm 3^{\mathrm{b}-\mathrm{e}}$ & $1.9 \pm 0.3^{\mathrm{b}-\mathrm{e}}$ & $0.4 \pm 0.11^{\mathrm{d}-\mathrm{i}}$ \\
\hline $\mathrm{FB}-50+\mathrm{D}$ & $46.3 \pm 3.1^{\mathrm{ef}}$ & $11.7 \pm 2.1^{\mathrm{h}-\mathrm{j}}$ & $15.7 \pm 2.5^{\mathrm{d}-\mathrm{g}}$ & $1.7 \pm 0.1^{g-j}$ & $0.5 \pm 0.05^{\mathrm{g}-\mathrm{i}}$ \\
\hline RS-65 & $46.7 \pm 3.2^{\mathrm{ef}}$ & $16.0 \pm 1^{\mathrm{d}-\mathrm{f}}$ & $21.3 \pm 3.1^{\mathrm{ab}}$ & $1.5 \pm 0.4^{\mathrm{e}-\mathrm{i}}$ & $0.3 \pm 0.09^{\mathrm{e}-\mathrm{i}}$ \\
\hline RS-65 +D & $39.3 \pm 2.5^{\mathrm{hi}}$ & $11.0 \pm 2^{\mathrm{h}-\mathrm{j}}$ & $18.0 \pm 2^{\mathrm{b}-\mathrm{e}}$ & $1.1 \pm 0.2^{\mathrm{ij}}$ & $0.2 \pm 0.05^{\mathrm{j}-\mathrm{k}}$ \\
\hline FB- 49 & $61.0 \pm 1.7^{\mathrm{b}}$ & $20.3 \pm 1.5^{\mathrm{ab}}$ & $21.3 \pm 2.1^{\mathrm{ab}}$ & $2.2 \pm 0.4^{\mathrm{bc}}$ & $0.60 .03^{\mathrm{bc}}$ \\
\hline $\mathrm{FB}-49+\mathrm{D}$ & $51.7 \pm 1.5^{\mathrm{d}}$ & $18.7 \pm 1.5^{\mathrm{b}-\mathrm{d}}$ & $17.7 \pm 1.5^{\mathrm{c}-\mathrm{e}}$ & $1.8 \pm 0.1^{\mathrm{d}-\mathrm{h}}$ & $0.55 \pm 0.07^{\mathrm{c}-\mathrm{f}}$ \\
\hline RS-72 & $51.7 \pm 2.1^{\mathrm{d}}$ & $16.7 \pm 1.5^{\mathrm{c}-\mathrm{f}}$ & $18.3 \pm 2.5^{\mathrm{b}-\mathrm{d}}$ & $2.1 \pm 0.4^{\mathrm{b}-\mathrm{d}}$ & $0.5 \pm 0.12^{\mathrm{cd}}$ \\
\hline $\mathrm{RS}-72+\mathrm{D}$ & $44.0 \pm 2^{\mathrm{fg}}$ & $11.3 \pm 1.5^{\mathrm{h}-\mathrm{j}}$ & $13.7 \pm 1.5^{\mathrm{f}-\mathrm{i}}$ & $1.3 \pm 0.1^{g-i}$ & $0.4 \pm 0.1^{\mathrm{e}-\mathrm{h}}$ \\
\hline BS-19 & $48.3 \pm 1.5^{\mathrm{de}}$ & $14.0 \pm 1^{\mathrm{f}-\mathrm{h}}$ & $18.7 \pm 3.1^{\mathrm{b}-\mathrm{d}}$ & $2.2 \pm 0.3^{\mathrm{bc}}$ & $0.5 \pm 0.14^{\mathrm{c}-\mathrm{e}}$ \\
\hline BS $-19+\mathrm{D}$ & $40.3 \pm 2.5^{\mathrm{g}-\mathrm{i}}$ & $10.3 \pm 1.5^{\mathrm{ij}}$ & $13.0 \pm 2^{\mathrm{j}-\mathrm{i}}$ & $1.6 \pm 0.3^{\mathrm{d}-\mathrm{h}}$ & $0.4 \pm 0.04^{\mathrm{d}-\mathrm{f}}$ \\
\hline RS-79 & $43.3 \pm 2.5^{\mathrm{f}-\mathrm{h}}$ & $12.7 \pm 2.1^{\mathrm{g}-\mathrm{i}}$ & $15.3 \pm 1.5^{\mathrm{d}-\mathrm{g}}$ & $1.9 \pm 0.3^{\mathrm{c}-\mathrm{f}}$ & $0.4 \pm 0.11^{\mathrm{d}-\mathrm{h}}$ \\
\hline RS-79+D & $39.3 \pm 1.5^{\mathrm{hi}}$ & $8.7 \pm 1.5^{\mathrm{jk}}$ & $11.3 \pm 1.5^{\mathrm{i}-\mathrm{j}}$ & $1.4 \pm 0.2^{\mathrm{f}-\mathrm{i}}$ & $0.3 \pm 0.08^{g-j}$ \\
\hline PS-16 & $46.0 \pm 2^{\mathrm{ef}}$ & $11.0 \pm 1^{\mathrm{h}-\mathrm{j}}$ & $20.3 \pm 2.5^{b c}$ & $1.8 \pm 0.5^{\mathrm{c}-\mathrm{f}}$ & $0.3 \pm 0.12^{\mathrm{g}-\mathrm{i}}$ \\
\hline PS-16 +D & $39.7 \pm 2.5^{\mathrm{hi}}$ & $8.4 \pm 2.1^{\mathrm{jk}}$ & $15.7 \pm 2.5^{\mathrm{d}-\mathrm{g}}$ & $1.4 \pm 0.2^{\mathrm{g}-\mathrm{i}}$ & $0.2 \pm 0.06^{g-j}$ \\
\hline BS-45 & $51.0 \pm 2^{\mathrm{d}}$ & $11.3 \pm 1.5^{\mathrm{h}-\mathrm{j}}$ & $14.7 \pm 1.5^{\mathrm{e}-\mathrm{h}}$ & $2.4 \pm 0.2^{\mathrm{b}}$ & $0.4 \pm 0.15^{\mathrm{d}-\mathrm{i}}$ \\
\hline $\mathrm{BS}-45+\mathrm{D}$ & $42.7 \pm 2.1^{\mathrm{f}-\mathrm{h}}$ & $9.3 \pm 1.5^{\mathrm{i}-\mathrm{k}}$ & $11.0 \pm 1^{\mathrm{ij}}$ & $1.4 \pm 0.1^{\mathrm{g}-\mathrm{i}}$ & $0.2 \pm 0.08^{\mathrm{h}-\mathrm{k}}$ \\
\hline PS-2 & $41.3 \pm 1.5^{\mathrm{g}-\mathrm{i}}$ & $10.0 \pm 1^{\mathrm{i}-\mathrm{k}}$ & $18.3 \pm 1.5^{\mathrm{b}-\mathrm{d}}$ & $1.4 \pm 0.1^{\mathrm{g}-\mathrm{i}}$ & $0.2 \pm 0.07^{\mathrm{g}-\mathrm{j}}$ \\
\hline PS-2 +D & $38.7 \pm 2.1^{\mathrm{i}}$ & $8.3 \pm 1.5^{\mathrm{jk}}$ & $11.7 \pm 2.1^{\mathrm{h}-\mathrm{j}}$ & $1.2 \pm 0.1^{\mathrm{h}-\mathrm{i}}$ & $0.2 \pm 0.02^{\mathrm{i}-\mathrm{k}}$ \\
\hline Consortia & $70.3 \pm 1.5^{\mathrm{a}}$ & $22.3 \pm 2.1^{\mathrm{a}}$ & $23.7 \pm 1.5^{\mathrm{a}}$ & $2.9 \pm 0.3^{\mathrm{a}}$ & $0.9 \pm 0.12^{\mathrm{a}}$ \\
\hline Consortia $+\mathrm{D}$ & $57.3 \pm 1.5^{\mathrm{c}}$ & $19.3 \pm 2.5^{\mathrm{bc}}$ & $16.7 \pm 2.8^{\mathrm{d}-\mathrm{f}}$ & $2.1 \pm 0.2^{\mathrm{b}-\mathrm{d}}$ & $0.8 \pm 0.07^{\mathrm{ab}}$ \\
\hline
\end{tabular}

Means with the same letter down the column are not significantly different at $(p \leq 0.05)$ by using DMRT. Mean \pm SD $(n=3)$; $D$ represents drought. Consortia $=$ FB-50 + BS-27 + BS-19 + FB-49. SH $=$ shoot height, $\mathrm{RL}=$ root length, SDW = shoot dry weight, RDW = root dry weight. 

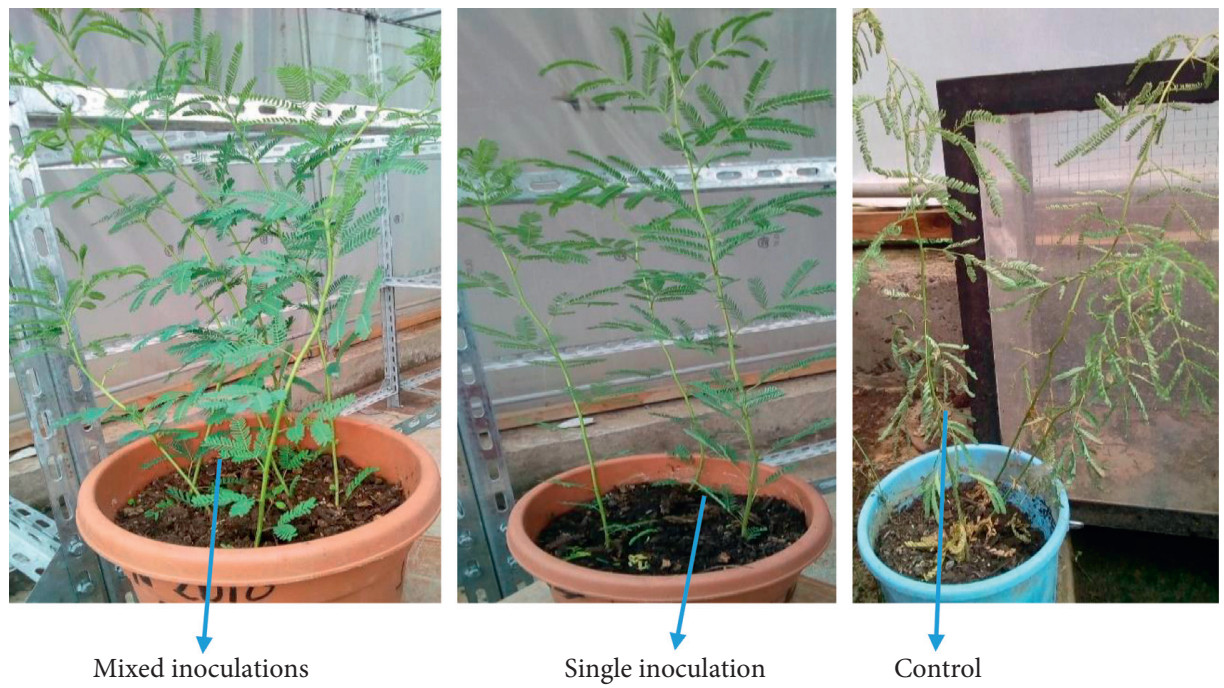

Figure 7: Drought stress enhancements of PGPR isolates in Acacia plants. Mixed = FB-50 + BS-27 + BS-19 + FB-49 + D; single = FB-49 + D; and control $=$ without inoculation $+\mathrm{D}$.

surfaces since biofilms provide important environmental reservoirs and protection for bacteria [55]. Biofilm assists drought tolerance by producing extracellular matrices to maintain a hydrated root environment, increasing rootadhering soil and stability [49]. Biofilms contain sugars and oligo- and polysaccharides that can play various roles in bacteria-plant interactions, e.g., in improving water availability in the root medium. Several studies have shown that different chemical substances or physical parameters affect the biofilm expression such as $\mathrm{NaCl}$ concentration and presence or absence of oxygen [29]. Besides, the process of biofilm is affected by several factors such as temperature, $\mathrm{pH}$, nutrients content, salinity, contact surface properties, and microbial strains [56].

The present finding confirms that the best situation for EPS production by PGPR isolates was found to be a basic medium supplemented with sucrose at $\mathrm{pH} 7 \pm 0.2$ and a temperature of $28 \pm 2^{\circ} \mathrm{C}$. The formation of EPSs by rhizobacteria is one of the important mechanisms in exerting drought tolerance. Based on the qualitative results, it was found that environmental stresses such as $\mathrm{pH}$ and temperature stimulated the production of EPS. Higher EPS production has been indicated in culture media supplemented with sucrose and glucose [57]. These variations are due to the kinds of sugar used and enzymatic metabolism of each strain [58] and the activity of glucosyltransferases $[59,60]$. EPS is fundamental for microbial life and provides an ideal environment for chemical reactions, nutrient entrapment, and protection against environmental stresses such as salinity and drought [61]. The EPS plays an important role in soil aggregation, thereby improving soil water holding capacity and soil fertility as observed in Azospirillum [15, 62]. Bacterial EPS production is one mechanism to survive under stressful (drought) conditions [63].

This study finds a wider range of $\mathrm{NaCl}$ tolerance although higher concentration brings a drastic decline in bacterial growth. It was observed that the extent to which growth was suppressed was directly proportional to the increasing concentration of $\mathrm{NaCl}$. Therefore, some of the salt-tolerant isolates (in this study) had good saprophytic and competitive abilities to perform well in drought-stressed conditions. It seems that this high osmotic strength is due to the production of proline, glutamate, glycine, betaine, and trehalose in the cells. $\mathrm{Na}^{+}$accumulation declines soil porosity, soil aeration, and water conductance. High $\mathrm{Na}^{+}$ions also interfere with $\mathrm{K}^{+}$and $\mathrm{Ca}^{2+}$ and affect enzymatic activities [64]. Soil bacteria inhabiting salty and arid ecosystems have the potential to promote plant growth under salinity and drought conditions [65]. Drought conditions are accompanied by an increase in temperature, changes in soil $\mathrm{pH}$, heavy metals, and salinity. Therefore, the successful deployment of PGPR in stressed ecosystems depends on their ability to withstand and proliferates under adverse environments [66].

Seven isolates were identified with high-temperature $\left(45^{\circ} \mathrm{C}\right)$ tolerance. Among tested strains, Bacillus spp. exhibited higher tolerance of temperature than Pseudomonas spp. One possible reason for this is due to the synthesis of heat-shock proteins [50] and also the presence of extremely resistant and dormant endospores produced by Bacillus spp. [67]. Similarly, the formation of endospores by Bacillus isolates could enhance their tolerance to high temperature [45]. Moreover, [67] highlighted that Bacillus endospores are extremely resistant and capable of withstanding unfavorable conditions. A thermotolerant $P$. putida NBRI0987 was isolated from the drought-affected rhizosphere of chickpea (Cicer arietinum) [68]. Another study has reported that a strain of Pseudomonas AKM-P6 possessing plant growthpromoting properties enhanced the tolerance of sorghum seedlings to high temperatures $\left(47-50^{\circ} \mathrm{C}\right)$. Studies suggested that rhizobacterial isolates RR-1, GGP-1, and GNR-1 were both tolerant to high temperature $\left(45^{\circ} \mathrm{C}\right)$ and also exhibited multiple beneficial plant growth-promoting activities [69]. Although in vitro temperature selection is not considered as a promising approach for field applications, but high 
temperature tolerance can be useful for isolating competitive PGPR in oscillating temperature in the fields [70].

In this study, four isolates $P$. polymyxa strain FB-50, A. calcoaceticus stain BS-27, P. putida strain BS-19, and P. fluorescens strain FB-49 showed $100 \%$ tolerance to all HMs tested. The result revealed that PGPR showed sensitivity to the different concentrations of HMs applied. The tolerance of Paenibacillus spp and B. thuringiensis to HMs like $\mathrm{Cd}, \mathrm{Cu}$, and $\mathrm{Zn}$ was also reported in [71]. Pseudomonas sp. showed a $97.9 \% \mathrm{~Pb}, 93.5 \% \mathrm{Cd}$, and $68 \%$ $\mathrm{Cu}$ removal efficiency from contaminated industrial wastewater is reported [72]. Surface binding/reduced uptake, increased efflux intracellular sequestration, enzyme detoxication, and active transport are among the proven mechanisms of tolerance [73]. Hence, these isolates could be useful in the bioremediation of HM-polluted environments.

The results of this study proved that the inoculation of PGPR isolates alone or in consortia had a significant effect in acacia growth under controlled conditions and also ameliorates the negative effect of drought stress. Inoculation with consortia showed the best plant growth performance and enhanced drought tolerance owing to their synergistic benefits in order to enhance plant growth. Similarly, inoculation with individual strains also improved plant biomass SH, RL, leave numbers, SDW, and RDW compared to the control. P. fluorescens strain FB-49 resulted in the highest biomass increase in under water restriction followed by $P$. polymyxa FB-50. Bacterial inoculation significantly increased the biomass of palm under drought, thereby contributing an essential ecological service to the entire oasis ecosystem. The possible mechanisms associated with PGPR-derived drought tolerance include alterations in host root system architecture, osmoregulation, management of oxidative stress, production of EPS, and transcriptional regulation of host stress response genes [47, 52, 74, 75]. Moreover, PGPR maintains the water budget of plants by improving the growth of the root system. This improves the water use efficiency and water absorption ability of roots under water scarcity [76]. Inoculation of plants with PGPR increases the growth rate/yield and fosters seedlings emergence in plants under greenhouse trials [77] and enhanced the root system (up to 40\%) in pepper [78]. Also, in [79], it is reported that inoculation with Enterobacter spp and Klebsiella spp increased in the dry matter of Lupinus albescens by 75 and $81 \%$, respectively, compared to the control. The application of Bacillus subtilis (BERA 71) turned out to be potentially beneficial in ameliorating the deleterious impact of salinity and drought in Acacia gerrardii [80]. Drought enhancement in Sambucus williamsii via the inoculation of $A$. calcoaceticus X128 was reported [81]. P. polymyxa enhanced the drought tolerance in Arabidopsis thaliana [82]. Acinetobacter spp and Pseudomonas spp enhanced the shoot and leaf biomasses of drought-challenged grapevines indicating the PGP activity of phytobeneficial microbes [83]. This study suggests the integrative use of a combination and/or single application of PGPR strains to be a promising and eco-friendly strategy for reducing moisture stress in plants.

\section{Conclusion}

This study revealed that PGPR strains recovered from degraded lands in Ethiopia have exhibited a promising abiotic stress-tolerance capacity. Some bacterial strains were considered completely tolerant (CT) to induced osmotic stress. Most of the bacterial isolates were biofilm formers and EPS producers which play protective roles under stressing conditions. Some PGPR strains such as $P$. polymyxa, A. calcoaceticus, $P$. putida, and $P$. fluorescens enhanced the drought stress tolerance in acacia under greenhouse conditions. Mixed inoculation resulted in higher drought tolerance in comparison to single inoculation. Thus, the elite indigenous strains identified in this study are potentially used in field trials to confirm their performance and applicability for the rehabilitation of degraded environments.

\section{Data Availability}

The data used to support the study are included within the manuscript. Data with all replicates can be made available from the corresponding author upon request.

\section{Conflicts of Interest}

The authors declare that there are no conflicts of interest.

\section{Acknowledgments}

The authors thank the Laboratory of Soil Biotechnology of the Embrapa Soja for molecular characterization of bacteria and Addis Ababa University for administrative support and sponsoring. This work was supported by the thematic research (grant number TR- 6223) of Addis Ababa University.

\section{Supplementary Materials}

Supplementary Figure S1: detection of biofilm production by Congo red agar (CRA) method. Supplementary Figure S2: detection of biofilm production by the tube method (TM) Supplementary Figure S3: translucent colony, potentially producing EPS, and control without EPS production. (Supplementary Materials)

\section{References}

[1] M. T. Kahil, A. Dinar, and J. Albiac, "Modeling water scarcity and droughts for policy adaptation to climate change in arid and semiarid regions," Journal of Hydrology, vol. 522, pp. 95-109, 2015.

[2] B. R. Glick, "Bacteria with ACC deaminase can promote plant growth and help to feed the world," Microbiological Research, vol. 169, no. 1, pp. 30-39, 2014.

[3] Y. Ma, H. Freitas, and M. Vosatka, "Beneficial microbes alleviate climatic stresses in plants," Frontiers in Plant Science, vol. 10, p. 595, 2019.

[4] N. Khan, A. Bano, M. A. Rahman, B. Rathinasabapathi, and M. A. Babar, "UPLC-HRMS-based untargeted metabolic 
profiling reveals changes in chickpea (Cicer arietinum) metabolome following long-term drought stress," Plant, Cell \& Environment, vol. 42, no. 1, pp. 115-132, 2019.

[5] J. F. Reynolds, D. M. S. Smith, E. F. Lambin et al., "Global desertification: building a science for dryland development," Science, vol. 316, no. 5826, pp. 847-851, 2007.

[6] W. A. Kasim, M. E. Osman, M. N. Omar, I. A. Abd El-Daim, S. Bejai, and J. Meijer, "Control of drought stress in wheat using plant-growth-promoting bacteria," Journal of Plant Growth Regulation, vol. 32, no. 1, pp. 122-130, 2013.

[7] I. Shiklomanov and J. C. Rodda, "World water resources at the beginning of the 21st century," in International Hydrology SeriesCambridge University Press, Cambridge, UK, 2003.

[8] M. M. Chaves, J. Flexas, and C. Pinheiro, "Photosynthesis under drought and salt stress: regulation mechanisms from whole plant to cell," Annals of Botany, vol. 103, no. 4, pp. 551-560, 2009.

[9] A. R. Saleem, C. Brunetti, A. Khalid et al., "Drought response of Mucuna pruriens (L.) DC. inoculated with ACC deaminase and IAA producing rhizobacteria," PLoS One, vol. 13, Article ID e0191218, 2018.

[10] M. Chodak, M. Gołębiewski, J. Morawska-Płoskonka, K. Kuduk, and M. Niklińska, "Soil chemical properties affect the reaction of forest soil bacteria to drought and rewetting stress," Annals of Microbiology, vol. 65, no. 3, pp. 1627-1637, 2015.

[11] M. Kaushal, "Microbes in cahoots with plants: MIST to hit the jackpot of agricultural productivity during drought," International Journal of Molecular Sciences, vol. 20, no. 7, p. 1769, 2019.

[12] Y. Bashan, L. E. de-Bashan, S. R. Prabhu, and J.-P. Hernandez, "Advances in plant growth-promoting bacterial inoculant technology: formulations and practical perspectives (19982013)," Plant and Soil, vol. 378, no. 1-2, pp. 1-33, 2014.

[13] S. Y. Asari, Studies on Plant-Microbe Interaction to Improve Stress Tolerance in Plants for Sustainable Agriculture, Acta Universitatis Agriculturae Sueciae, Uppsala, Sweden, 2015.

[14] H. Zhang, C. Murzello, Y. Sun et al., "Choline and osmoticstress tolerance induced in Arabidopsis by the soil microbe Bacillus subtilis (GB03)," Molecular Plant-Microbe Interactions, vol. 23, no. 8, pp. 1097-1104, 2010.

[15] V. Sandhya, S. Z. Ali, M. Grover, G. Reddy, and B. Venkateswarlu, "Effect of plant growth promoting Pseudomonas spp. on compatible solutes, antioxidant status and plant growth of maize under drought stress," Plant Growth Regulation, vol. 62, no. 1, pp. 21-30, 2010.

[16] S. Shilev, "Soil rhizobacteria regulating the uptake of nutrients and undesirable elements by plants," in Plant Microbe Symbiosis: Fundamentals and Advances, pp. 147-167, Springer, Berlin, Germany, 2013.

[17] B. G. Kang, W. T. Kim, H. S. Yun, and S. C. Chang, "Use of plant growth-promoting rhizobacteria to control stress responses of plant roots," Plant Biotechnology Reports, vol. 4, no. 3, pp. 179-183, 2010.

[18] V. Sandhya, S. Ali, M. Grover, N. Kishore, and B. Venkateswarlu, "Pseudomonas sp. strain P45 protects sunflowers seedlings from drought stress through improved soil structure," Journal of Oilseeds Research, vol. 26, pp. 600-601, 2009.

[19] P. Das, B. K. Behera, D. K. Meena et al., "Salt stress tolerant genes in halophilic and halotolerant bacteria: paradigm for salt stress adaptation and osmoprotection," International Journal of Current Microbiology and Applied Sciences, vol. 4, no. 1, pp. 642-658, 2015.
[20] E. Raddad and O. Luukkanen, "Dryland rehabilitation with Acacia Senegal in the central clay plain of the Sudan: implications for ecological sustainability and management interventions," Sudan Journal of Agricultural Research, vol. 22, pp. 31-48, 2013.

[21] M. H. Mohamed, The Importance of Acacia senegal L. As a Major Species of Gum Arabic Belt Rehabilitation at Dilling Area, Sudan University of Science and Technology, Khartoum, Sudan, 2006.

[22] A. Getahun, D. Muleta, F. Assefa, S. Kiros, and M. Hungria, "Biochar and other organic amendments improve the physicochemical properties of soil in highly degraded habitat," European Journal of Engineering Research and Science, vol. 5, no. 3, pp. 331-338, 2020.

[23] S. Pingping, C. Jianchao, J. Xiaohui, and W. Wenhui, "Isolation and characterization of Bacillus amyloliquefaciens L-1 for biocontrol of pear ring rot," Horticultural Plant Journal, vol. 3, no. 5, pp. 183-189, 2017.

[24] W. G. Weisburg, S. M. Barns, D. A. Pelletier, and D. J. Lane, "16S ribosomal DNA amplification for phylogenetic study," Journal of Bacteriology, vol. 173, no. 2, pp. 697-703, 1991.

[25] J. Versalovic, M. Schneider, F. De Bruijn, and J. R. Lupski, "Genomic fingerprinting of bacteria using repetitive sequence-based polymerase chain reaction," Methods in Molecular and Cellular Biology, vol. 5, pp. 25-40, 1994.

[26] F. Paulitsch, M. S. Klepa, A. R. da Silva et al., "Phylogenetic diversity of rhizobia nodulating native Mimosa gymnas grown in a South Brazilian ecotone," Molecular Biology Reports, vol. 46, no. 1, pp. 529-540, 2019.

[27] S. Kumar, G. Stecher, and K. Tamura, "MEGA7: molecular evolutionary genetics analysis version 7.0 for bigger datasets," Molecular Biology and Evolution, vol. 33, no. 7, pp. 1870-1874, 2016.

[28] H. Alikhani and L. Mohamadi, "Assessing tolerance of rhizobial lentil symbiosis isolates to salinity and drought in dry land farming condition," in Proceedings of the 19th World Congress of Soil Science, Soil Solutions for a Changing World, pp. 1-6, Brisbane, Australia, 2010.

[29] N. S. Mariana, S. Salman, V. K. Neela, and S. Zamberi, "Evaluation of modified Congo red agar for detection of biofilm produced by clinical isolates of methicillinresistance Staphylococcus aureus," African Journal of Microbiology Research, vol. 3, no. 6, pp. 330-338, 2009.

[30] T. Mathur, S. Singhal, S. Khan, D. Upadhyay, T. Fatma, and A. Rattan, "Detection of biofilm formation among the clinical isolates of staphylococci: an evaluation of three different screening methods," Indian Journal of Medical Microbiology, vol. 24, no. 1, p. 25, 2006.

[31] A. F. Mohammed, "Effectiveness of exopolysaccharides and biofilm forming plant growth promoting rhizobacteria on salinity tolerance of faba bean (Vicia faba L.)," African Journal of Microbiology Research, vol. 12, no. 17, pp. 399-404, 2018.

[32] E. M. Paulo, M. P. Vasconcelos, I. S. Oliveira et al., "An alternative method for screening lactic acid bacteria for the production of exopolysaccharides with rapid confirmation," Food Science and Technology, vol. 32, no. 4, pp. 710-714, 2012.

[33] S. Legesse and F. Assefa, "Symbiotic and phenotypic characteristics of rhizobia nodulating faba bean (Vicia Faba) from Tahtay Koraro, northwestern zone of Tigray Regional State, Ethiopia," International Journal of Emerging Engineering Research and Technology, vol. 2, pp. 15-23, 2014.

[34] S. B. Romdhane, M. Trabelsi, M. E. Aouani, P. De Lajudie, and R. Mhamdi, "The diversity of rhizobia nodulating chickpea (Cicer arietinum) under water deficiency as a source of more 
efficient inoculants," Soil Biology and Biochemistry, vol. 41, pp. 2568-2572, 2009.

[35] Ç. Küçük, M. Kivanç, and E. Kinaci, "Characterization of Rhizobium sp. isolated from bean," Turkish Journal of Biology, vol. 30, pp. 127-132, 2006.

[36] S. Lee, M. Najiah, W. Wendy, A. Zahrol, and M. Nadirah, "Multiple antibiotic resistance and heavy metal resistance profile of bacteria isolated from giant freshwater prawn (Macrobrachium rosenbergii) hatchery," Agricultural Sciences in China, vol. 8, no. 6, pp. 740-745, 2009.

[37] P. Messi, E. Guerrieri, and M. Bondi, "Antibiotic resistance and antibacterial activity in heterotrophic bacteria of mineral water origin," Science of the Total Environment, vol. 346, no. 1-3, pp. 213-219, 2005.

[38] M.-H. Hung, A. A. Bhagwath, F.-T. Shen, R. P. Devasya, and C.-C. Young, "Indigenous rhizobia associated with native shrubby legumes in Taiwan," Pedobiologia, vol. 49, no. 6, pp. $577-584,2005$.

[39] C. Jones, S. Jensen, and M. Stevens, "An evaluation of seed scarification methods of four native Lupinus species," in Proceedings of the Seed Ecology III-The Third International Society for Seed Science Meeting on Seeds and the Environment-"Seeds and Change", US Department of Agriculture, Forest Service, Rocky Mountain Research Station, Salt Lake City, UT, USA, pp. 74-75, June 2010.

[40] M. B. Mia, Z. Shamsuddin, and M. Mahmood, "Effects of rhizobia and plant growth promoting bacteria inoculation on germination and seedling vigor of lowland rice," African Journal of Biotechnology, vol. 11, no. 6, pp. 3758-3765, 2012.

[41] F. Magnani, M. Centritto, and J. Grace, "Measurement of apoplasmic and cell-to-cell components of root hydraulic conductance by a pressure-clamp technique," Planta, vol. 199, no. 2, pp. 296-306, 1996.

[42] M. Kumar, S. Mishra, V. Dixit et al., "Synergistic effect of Pseudomonas putida and Bacillus amyloliquefaciens ameliorates drought stress in chickpea (Cicer arietinum L.)," Plant Signaling \& Behavior, vol. 11, Article ID e1071004, 2016.

[43] K. Tamura, G. Stecher, D. Peterson, A. Filipski, and S. Kumar, "MEGA6: molecular evolutionary genetics analysis version 6.0," Molecular Biology and Evolution, vol. 30, no. 12, pp. 2725-2729, 2013.

[44] A. Rehman and C. S. Nautiyal, "Effect of drought on the growth and survival of the stress-tolerant bacterium Rhizobium sp. NBRI2505 sesbania and its drought-sensitive transposon tn 5 mutant," Current Microbiology, vol. 45, no. 5, pp. 368-377, 2002.

[45] G. Praveen Kumar, S. Mir Hassan Ahmed, S. Desai, E. Leo Daniel Amalraj, and A. Rasul, "In Vitro screening for abiotic stress tolerance in potent biocontrol and plant growth promoting strains of Pseudomonas and Bacillus spp," International Journal of Bacteriology, vol. 2014, Article ID 195946, 2014.

[46] A. Susilowati, A. Puspita, and A. Yunus, "Drought resistant of bacteria producing exopolysaccharide and IAA in rhizosphere of soybean plant (Glycine max) in Wonogiri Regency Central Java Indonesia," IOP Conference Series: Earth and Environmental Science, vol. 142, no. 1, Article ID 012058, 2018.

[47] S. S. K. P. Vurukonda, S. Vardharajula, M. Shrivastava, and A. SkZ, "Enhancement of drought stress tolerance in crops by plant growth promoting rhizobacteria," Microbiological Research, vol. 184, pp. 13-24, 2016.

[48] V. N. Kavamura, S. N. Santos, J. L. d. Silva et al., "Screening of Brazilian cacti rhizobacteria for plant growth promotion under drought," Microbiological Research, vol. 168, no. 4, pp. 183-191, 2013.

[49] V. Sandhya, A. Sk, M. Grover, G. Reddy, and B. Venkateswarlu, "Alleviation of drought stress effects in sunflower seedlings by the exopolysaccharides producing Pseudomonas putida strain GAP-P45," Biology and Fertility of Soils, vol. 46, no. 1, pp. 17-26, 2009.

[50] S. Z. Ali, V. Sandhya, M. Grover, N. Kishore, L. V. Rao, and B. Venkateswarlu, "Pseudomonas sp. strain AKM-P6 enhances tolerance of sorghum seedlings to elevated temperatures," Biology and Fertility of Soils, vol. 46, no. 1, pp. 45-55, 2009.

[51] Y.-C. Kim, B. R. Glick, Y. Bashan, and C.-M. Ryu, "Enhancement of plant drought tolerance by microbes," in Plant Responses to Drought Stress, pp. 383-413, Springer, Berlin, Germany, 2012.

[52] S. Timmusk, I. A. A. El-Daim, L. Copolovici et al., "Droughttolerance of wheat improved by rhizosphere bacteria from harsh environments: enhanced biomass production and reduced emissions of stress volatiles," PLoS One, vol. 9, Article ID e96086, 2014.

[53] S.-M. Cho, B. R. Kang, and Y. C. Kim, "Transcriptome analysis of induced systemic drought tolerance elicited by Pseudomonas chlororaphis O6 in Arabidopsis thaliana," The Plant Pathology Journal, vol. 29, no. 2, p. 209, 2013.

[54] Y. Pan, F. Breidt, and L. Gorski, "Synergistic effects of sodium chloride, glucose, and temperature on biofilm formation by Listeria monocytogenes serotype $1 / 2 \mathrm{a}$ and $4 \mathrm{~b}$ strains," Applied and Environmental Microbiology, vol. 76, no. 5, pp. 14331441, 2010.

[55] G. B. Whitfield, L. S. Marmont, and P. L. Howell, "Enzymatic modifications of exopolysaccharides enhance bacterial persistence," Frontiers in Microbiology, vol. 6, p. 471, 2015.

[56] H. Xu, Y. Zou, H.-Y. Lee, and J. Ahn, "Effect of $\mathrm{NaCl}$ on the biofilm formation by foodborne pathogens," Journal of Food Science, vol. 75, no. 9, pp. M580-M585, 2010.

[57] F. Sarwat, S. A. U. Qader, A. Aman, and N. Ahmed, "Production \& characterization of a unique dextran from an indigenous leuconostoc mesenteroides CMG713," International Journal of Biological Sciences, vol. 4, p. 379, 2008.

[58] P. Ruas-Madiedo and C. G. de los Reyes-Gavilán, "Invited review: methods for the screening, isolation, and characterization of exopolysaccharides produced by lactic acid bacteria," Journal of Dairy Science, vol. 88, no. 3, pp. 843-856, 2005.

[59] N. O. Igiehon, O. O. Babalola, and B. R. Aremu, "Genomic insights into plant growth promoting rhizobia capable of enhancing soybean germination under drought stress," BMC Microbiology, vol. 19, p. 159, 2019.

[60] L. Canilha, D. Silva, W. Carvalho, and M. Mancilha, “Aditivos alimentares produzidos por via fermentativa parte 3: polissacarídeos e enzimas," Revista Analytica, vol. 20, pp. 32-41, 2006.

[61] O. Y. Costa, J. M. Raaijmakers, and E. E. Kuramae, "Microbial extracellular polymeric substances: ecological function and impact on soil aggregation," Frontiers in Microbiology, vol. 9, pp. 1-8, 2018.

[62] Y. Bashan, G. Holguin, and L. E. De-Bashan, “Azospirillumplant relationships: physiological, molecular, agricultural, and environmental advances (1997-2003)," Canadian Journal of Microbiology, vol. 50, no. 8, pp. 521-577, 2004.

[63] R. F. W. Putrie, A. T. Wahyudi, A. A. Nawangsih, and E. Husen, "Screening of rhizobacteria for plant growth promotion and their tolerance to drought stress," Microbiology Indonesia, vol. 7, no. 2, 2013. 
[64] P. Diby and L. Harshad, "Plant-growth-promoting rhizobacteria to improve crop growth in saline soils: a review," Agronomy for Sustainable Development, vol. 34, pp. 737-752, 2015.

[65] F. Mapelli, R. Marasco, E. Rolli et al., "Potential for plant growth promotion of rhizobacteria associated with Salicornia growing in Tunisian hypersaline soils," BioMed Research International, vol. 2013, Article ID 248078, 2013.

[66] S. Gopalakrishnan, A. Sathya, R. Vijayabharathi, R. K. Varshney, C. L. L. Gowda, and L. Krishnamurthy, "Plant growth promoting rhizobia: challenges and opportunities," 3 Biotech, vol. 5, no. 4, pp. 355-377, 2015.

[67] P. J. Piggot and D. W. Hilbert, "Sporulation of Bacillus subtilis," Current Opinion in Microbiology, vol. 7, no. 6, pp. 579-586, 2004.

[68] S. Srivastava, A. Yadav, K. Seem, S. Mishra, V. Chaudhary, and C. S. Nautiyal, "Effect of high temperature on Pseudomonas putida NBRI0987 biofilm formation and expression of stress sigma factor RpoS," Current Microbiology, vol. 56, no. 5, pp. 453-457, 2008.

[69] K. Manasa, R. Subhash, and S. Trivenu, "In vitro screening of temperature stress tolerance of Rhizobial and Pseudomonas fluorescence isolates," Journal of Pharmacognosy and Phytochemistry, vol. 6, pp. 764-767, 2017.

[70] M. Hungria and M. A. T. Vargas, "Environmental factors affecting N2 fixation in grain legumes in the tropics, with an emphasis on Brazil," Field Crops Research, vol. 65, no. 2-3, pp. 151-164, 2000.

[71] I. Rathnayake, M. Megharaj, N. Bolan, and R. Naidu, “Tolerance of heavy metals by gram positive soil bacteria," World Academy of Science Engineering and Technology, vol. 3, no. 5, 2009.

[72] A. M. Azzam and A. Tawfik, "Removal of heavy metals using bacterial bio-flocculants of Bacillus sp. and Pseudomonas sp," Journal of Environmental Engineering and Landscape Management, vol. 23, no. 4, pp. 288-294, 2015.

[73] D. H. Nies, "Resistance to cadmium, cobalt, zinc, and nickel in microbes," Plasmid, vol. 27, no. 1, pp. 17-28, 1992.

[74] I. Gontia-Mishra, S. Sapre, A. Sharma, and S. Tiwari, "Amelioration of drought tolerance in wheat by the interaction of plant growth-promoting rhizobacteria," Plant Biology, vol. 18, pp. 992-1000, 2016.

[75] C. Forni, D. Duca, and B. R. Glick, "Mechanisms of plant response to salt and drought stress and their alteration by rhizobacteria," Plant and Soil, vol. 410, no. 1-2, pp. 335-356, 2017.

[76] M. Kaushal and S. P. Wani, "Plant-growth-promoting rhizobacteria: drought stress alleviators to ameliorate crop production in drylands," Annals of Microbiology, vol. 66, no. 1, pp. 35-42, 2016.

[77] O. A. Almaghrabi, S. I. Massoud, and T. S. Abdelmoneim, "Influence of inoculation with plant growth promoting rhizobacteria (PGPR) on tomato plant growth and nematode reproduction under greenhouse conditions," Saudi Journal of Biological Sciences, vol. 20, no. 1, pp. 57-61, 2013.

[78] R. Marasco, E. Rolli, G. Vigani et al., "Are drought-resistance promoting bacteria cross-compatible with different plant models?” Plant Signaling \& Behavior, vol. 8, no. 10, Article ID e26741, 2013.

[79] A. Giongo, A. Beneduzi, A. Ambrosini et al., "Isolation and characterization of two plant growth-promoting bacteria from the rhizoplane of a legume (Lupinus albescens) in sandy soil," Revista Brasileira de Ciência do Solo, vol. 34, no. 2, pp. 361-369, 2010.
[80] A. Hashem, E. F. Abd_Allah, A. A. Alqarawi, A. A. Al-Huqail, and M. A. Shah, "Induction of osmoregulation and modulation of salt stress inAcacia gerrardiiBenth. By arbuscular mycorrhizal fungi andBacillus subtilis(BERA 71)," BioMed Research International, vol. 2016, Article ID 6294098, 11 pages, 2016.

[81] F. Liu, H. Ma, L. Peng, Z. Du, B. Ma, and X. Liu, "Effect of the inoculation of plant growth-promoting rhizobacteria on the photosynthetic characteristics of Sambucus williamsii Hance container seedlings under drought stress," AMB Express, vol. 9, no. 1, pp. 1-9, 2019.

[82] S. Timmusk and E. G. H. Wagner, "The plant-growth-promoting rhizobacterium Paenibacillus polymyxa induces changes in Arabidopsis thaliana gene expression: a possible connection between biotic and abiotic stress responses," Molecular Plant-Microbe Interactions, vol. 12, no. 11, pp. 951-959, 1999.

[83] E. Rolli, R. Marasco, G. Vigani et al., "Improved plant resistance to drought is promoted by the root-associated microbiome as a water stress-dependent trait," Environmental Microbiology, vol. 17, no. 2, pp. 316-331, 2015. 